\title{
On the importance of cascading moisture recycling in South America
}

\author{
D. C. Zemp ${ }^{1,2}$, C.-F. Schleussner ${ }^{1,3}$, H. M. J. Barbosa ${ }^{4}$, R. J. van der Ent $^{5}$, J. F. Donges ${ }^{1,6}$, J. Heinke ${ }^{1,7}$, G. Sampaio ${ }^{8}$, \\ and A. Rammig ${ }^{1}$ \\ ${ }^{1}$ Potsdam Institute for Climate Impact Research (PIK), 14473 Potsdam, Germany \\ ${ }^{2}$ Department of Geography, Humboldt Universität zu Berlin, Berlin, Germany \\ ${ }^{3}$ Climate Analytics, Berlin, Germany \\ ${ }^{4}$ Instituto de Física, Universidade de São Paulo, São Paulo, S.P., Brazil \\ ${ }^{5}$ Department of Water Management, Faculty of Civil Engineering and Geosciences, Delft University of Technology, \\ Delft, the Netherlands \\ ${ }^{6}$ Stockholm Resilience Centre, Stockholm University, Stockholm, Sweden \\ ${ }^{7}$ International Livestock Research Institute (ILRI), Nairobi, Kenya \\ ${ }^{8}$ Center for Earth System Science (CCST), INPE, Cachoeira Paulista, S.P., Brazil
}

Correspondence to: D. C. Zemp (delphine.zemp@pik-potsdam.de)

Received: 12 May 2014 - Published in Atmos. Chem. Phys. Discuss.: 30 June 2014

Revised: 24 October 2014 - Accepted: 4 November 2014 - Published: 15 December 2014

\begin{abstract}
Continental moisture recycling is a crucial process of the South American climate system. In particular, evapotranspiration from the Amazon basin contributes substantially to precipitation regionally as well as over other remote regions such as the La Plata basin. Here we present an indepth analysis of South American moisture recycling mechanisms. In particular, we quantify the importance of cascading moisture recycling (CMR), which describes moisture transport between two locations on the continent that involves reevaporation cycles along the way. Using an Eulerian atmospheric moisture tracking model forced by a combination of several historical climate data sets, we were able to construct a complex network of moisture recycling for South America. Our results show that CMR contributes about 9-10\% to the total precipitation over South America and 17-18\% over the La Plata basin. CMR increases the fraction of total precipitation over the La Plata basin that originates from the Amazon basin from 18-23 to 24-29\% during the wet season. We also show that the south-western part of the Amazon basin is not only a direct source of rainfall over the La Plata basin, but also a key intermediary region that distributes moisture originating from the entire Amazon basin towards the La Plata basin during the wet season. Our results suggest that land use change in this region might have a stronger impact on
\end{abstract}

downwind rainfall than previously thought. Using complex network analysis techniques, we find the eastern side of the sub-tropical Andes to be a key region where CMR pathways are channeled. This study offers a better understanding of the interactions between the vegetation and the atmosphere on the water cycle, which is needed in a context of land use and climate change in South America.

\section{Introduction}

Continental moisture recycling, the process by which evapotranspiration from the continent returns as precipitation to the continent (Brubaker et al., 1993; Eltahir and Bras, 1994; van der Ent et al., 2010), is particularly important for the South American hydrological cycle. In the Amazon basin, between 25 and $35 \%$ of the moisture is regionally recycled (Eltahir and Bras, 1994; Trenberth, 1999; Bosilovich and Chern, 2006; Burde et al., 2006; Dirmeyer et al., 2009). Particularly during the wet season, the moisture from the Amazon basin is exported out of the basin, transported via the South American low-level jet (SALLJ) along the Andes and contributes to precipitation over the La Plata basin (Marengo, 2005; Drumond et al., 2008, 2014; Arraut and Satyamurty, 
2009; Dirmeyer et al., 2009; van der Ent et al., 2010; Arraut et al., 2012; Martinez et al., 2014).

Land use change - in particular deforestation in the Amazon basin - alters the evapotranspiration rate and affects the water cycle (see review in Marengo, 2006). A resulting reduction in regional moisture supply may have important consequences for the stability of Amazon rainforests (Oyama and Nobre, 2003; Cox et al., 2004; Betts et al., 2004; Hirota et al., 2011; Knox et al., 2011; Spracklen et al., 2012). In addition, downwind rainfall reduction may have negative effects on rainfed agriculture in the La Plata basin (Rockström et al., 2009; Keys et al., 2012). Even if the regional impact of changes in precipitation patterns from deforestation has been intensively studied using simulations from atmospheric general circulation models with deforestation scenarios (Lean and Warrilow, 1989; Shukla et al., 1990; Nobre et al., 1991, 2009; Werth and Avissar, 2002; Sampaio et al., 2007; Da Silva et al., 2008; Hasler et al., 2009; Walker et al., 2009; Medvigy et al., 2011; Bagley et al., 2014), the magnitude of rainfall reduction and the location of the most affected regions are still uncertain. In order to improve predictability of rainfall changes with future land use and climate change, further advancement in our understanding of continental moisture recycling in South America is needed.

To identify the sources and sinks of continental moisture and to quantify regional and continental moisture recycling rates in South America, several methods have been used including isotopes (Salati et al., 1979; Gat and Matsui, 1991; Victoria et al., 1991), atmospheric bulk models (Brubaker et al., 1993; Eltahir and Bras, 1994; Trenberth, 1999; Burde et al., 2006) and quasi-isentropic back-trajectory method (Dirmeyer et al., 2009; Spracklen et al., 2012; Bagley et al., 2014). In addition, an Eulerian numerical atmospheric moisture tracking experiment allows one to identify the spatial distribution of evapotranspiration from a specific region. It has been performed online with a general circulation model (Bosilovich and Chern, 2006) or a posteriori (offline) with reanalysis data (Sudradjat et al., 2002; van der Ent et al., 2010; Keys et al., 2012; see a review of the methods in van der Ent et al., 2013 and Burde and Zangvil, 2001).

In most of the previous atmospheric moisture tracking studies, moisture from a group of grid cells covering a region of interest (typically the continent) is tracked simultaneously until it returns to the land surface as precipitation or leaves the domain. This approach is useful for investigating how evapotranspiration from a specific location is transported in the atmosphere and precipitates at first in another location. However, precipitating moisture can be reevapotranspirated in the same location (re-evaporation cycle) and can be transported further downwind before it falls again as precipitation over land. In most of the previous studies, only moisture recycling with no intervening re-evaporation cycles (direct moisture recycling, DMR) is considered. Here, we track moisture evaporating from each grid cell within a larger domain (i.e., the South American continent) individu- ally. By doing so, we are able to diagnose for each grid cell the amount of evaporating moisture that precipitates in any other cell, i.e., to build a moisture recycling network. Such an approach enables us to study not only the DMR between important sub-regions of the South American continent (e.g., the Amazon and the La Plata basin), but also the moisture transport that involves at least one re-evaporation cycle (cascading moisture recycling, CMR).

While only a few previous studies deal with the importance of CMR (Numaguti, 1999; Goessling and Reick, 2013), these studies are based on general circulation models rather than on observation-based data. In the following, we quantify the importance of CMR for the regional climate in South America using numerical atmospheric moisture tracking a posteriori with historical climatological data sets. Our analysis is based on precipitation, evapotranspiration, wind and humidity data sets from a combination of observation-based, reanalysis and merged synthesis products (average of several existing products).

Our network-based approach allows us to apply analysis methods developed in complex network theory to improve our understanding of moisture recycling pathways in South America. The potential of complex network-based analysis of the climate system has been shown in a range of applications such as the detection of teleconnections (Tsonis et al., 2008; Donges et al., 2009a, b), the propagation of extreme events (Malik et al., 2012; Boers et al., 2013) and El Niño forecasting (Ludescher et al., 2013). While previous network-based studies relied on statistical analysis of correlations between time series in the network construction, our approach is based on a flux-based network, which represents a substantial methodological advancement.

In this study we focus on three key questions:

1. What is the importance of CMR in South America and in particular for the moisture transport from the Amazon basin towards the La Plata basin?

2. What are the important intermediary regions for the transport of moisture from sources to sinks on the continent?

3. What are the key regions where the pathways of CMR are channeled?

In Sect. 2.1 we describe the tagged water experiment using the Eulerian atmospheric moisture tracking model WAM2layers (Water Accounting Model- two layers) and we explain how we use it to build moisture recycling networks. We explain the assumptions made in the proposed analysis in Sect. 2.2. We develop new measures in Sects. 2.3 and 2.4 and we present the complex network analysis in Sect. 2.5. An explanation of the complementarity of the measures is presented in Sect. 2.6. After comparing the continental and regional recycling ratios with other existing studies in Sect. 3.1, we present and discuss new results on the importance of CMR in Sect. 3.2 and on complex network analysis 
Table 1. Input data sets used for building moisture recycling networks. The first year of the period is omitted from the results because of model spin-up.

\begin{tabular}{llll}
\hline Input name & Evapotranspiration product & Precipitation product & Period \\
\hline Input MOD & MODIS & TRMM & $2000-2010$ \\
Input LFE & LandFlux-EVAL & Average of CRU, GPCC, GPCP and CPC & 1989-1995 \\
\hline
\end{tabular}

in Sect. 3.3. We present an in-depth analysis of the moisture recycling between the Amazon basin and the La Plata basin in Sect. 3.4. Finally, we warn against possible effects of land use change in the intermediary regions in Sect. 3.5. As many terms have been introduced in this study, we refer the reader to the glossary in Appendix A.

\section{Methods}

\subsection{Building moisture recycling networks}

\subsubsection{Description of the moisture tagging experiment in WAM-2layers}

In this study we make use of the offline Eulerian atmospheric moisture tracking model WAM-2layers (Water Accounting Model-two layers) version 2.3.01 (van der Ent et al., 2014). It is an update of a previous version that has been used in a variety of publications focusing on moisture tracking and moisture recycling (e.g., van der Ent et al., 2010; van der Ent and Savenije, 2011; Keys et al., 2012). The actual tracking in WAM-2layers is performed a posteriori with two different data sets (see input data in Sect. 2.1.2). Evapotranspiration from each grid cell is tagged and subsequently tracked in the atmosphere by applying water balance principles to each grid cell, consisting of a well-mixed upper and lower part. The two-layer approach is simplified compared to full 3-D tracking, but was shown to perform comparably well (van der Ent et al., 2013).

The WAM-2layers runs on a $1.5^{\circ}$ longitude-latitude grid. Because the local moisture recycling is scale dependent, the amount of locally recycled moisture within a grid cell depends on the spatial resolution of the model (van der Ent and Savenije, 2011, Fig. 4). However, in our study, the reevaporation cycles are occurring along the pathway of moisture recycling. Since we are integrating over all pathways contributing to the large-scale moisture transport, the spatial resolution has little influence on our results. The typical length scale of direct links in moisture recycling is larger than $1000 \mathrm{~km}\left(\mathrm{ca} .9^{\circ}\right)$ in the region (van der Ent and Savenije, 2011, Fig. 5), which indicates that our resolution is sufficient to analyze the processes of interest.

We omitted the first year of the considered period from the results because of model spin-up. The outputs are aggregated first to monthly, then to seasonally average imports and exports between all land grid cells. This temporal resolution is reasonable for our purpose since the timescale of moisture recycling does not exceed 30 days in the studied region (van der Ent and Savenije, 2011, Fig. 5).

These seasonal averages are used to build two seasonal moisture recycling networks, which are assumed to be static for the whole season. This implies that in the proposed analysis, for each season moisture is tracked forward and backward in space but not in time.

\subsubsection{Input of WAM-2layers}

In order to reduce the uncertainty associated with the input data, we used two different data sets (that we call input MOD and input LFE; see Table 1) as input for WAM2layers. The input MOD covers the period 2000-2010 and contains 3-hourly precipitation estimates from the Tropical Rainfall Measuring Mission (TRMM) based on the algorithm 3B-42 (version 7) (Huffman et al., 2007) and 8 days of evapotranspiration estimates from Moderate Resolution Imaging Spectroradiometer (MODIS) based on the MOD16 ET algorithm (Mu et al., 2011). Precipitation data sets from TRMM are considered to be reliable over South America and in particular in the Amazon basin where others products perform poorly due to the lack of ground-based measurements (Franchito et al., 2009; Rozante et al., 2010). TRMM precipitation data are shown to represent high-frequency variability sufficiently well (Kim and Alexander, 2013). However, it is systematically biased during the dry season in the north-eastern coast of Brazil, where precipitation is underestimated (Franchito et al., 2009) and at the junction of Argentina, Paraguay and Brazil, where it is overestimated (Rozante and Cavalcanti, 2008). Evapotranspiration from MODIS is estimated using the Penman-Monteith equation (Monteith et al., 1965) forced by satellite and meteorological reanalysis data. Like other observation-based evapotranspiration estimations, the quality of the MODIS data set depends on the quality of the forcing data and the parameterization of the algorithm. The MODIS evapotranspiration data set has been validated with 10 eddy flux towers located in the Amazonian region under various land-cover types (Loarie et al., 2011; Ruhoff, 2011).

The input LFE covers the period 1989-1995 and contains monthly evapotranspiration averaged from 40 different products (LandFlux-EVAL, Mueller et al., 2013), as well as monthly precipitation averaged from four different observation-based precipitation data sets: Climate Research Unit (CRU) (New et al., 2000), the Global Precipitation Cli- 
Input MOD, dry season (JJAS)

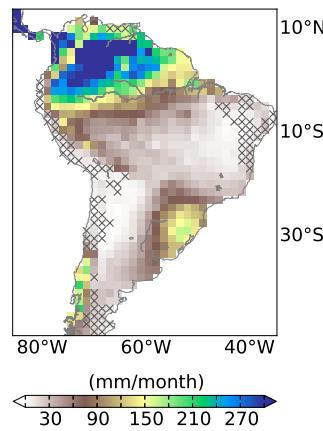

(a) Precip.

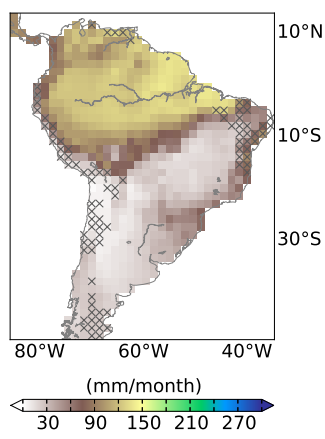

(b) Evap.

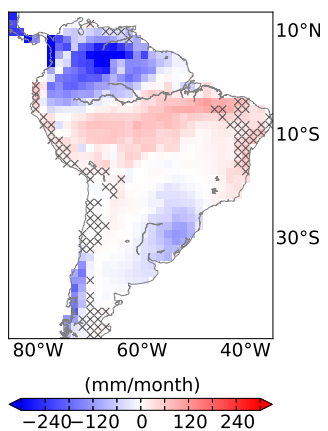

(c) Evap. - Precip.

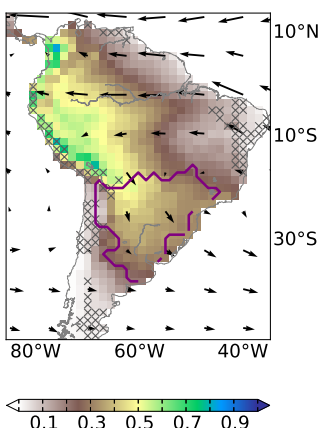

(d) $\rho_{c}$

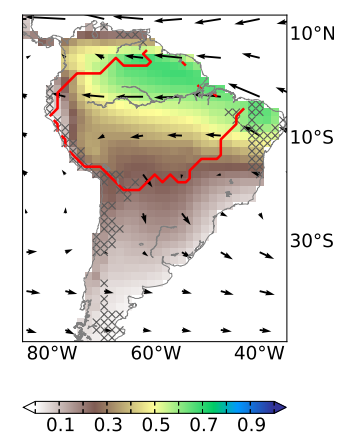

(e) $\varepsilon_{c}$

Input MOD, wet season (DJFM)

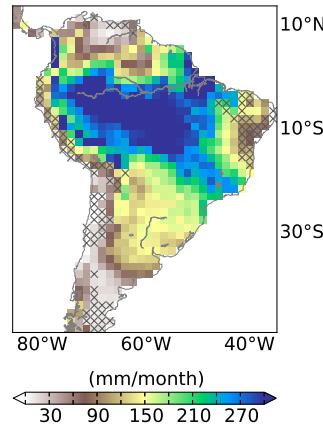

(f) Precip.

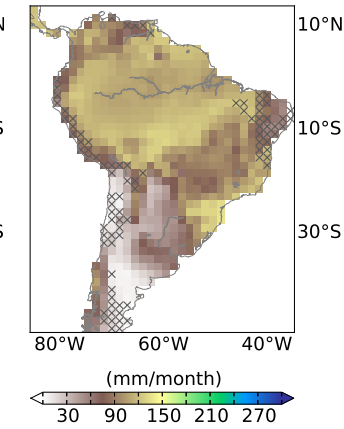

(g) Evap.

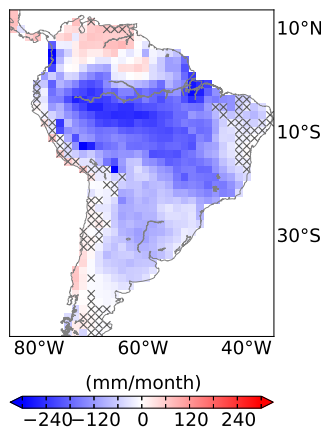

(h) Evap. - Precip.

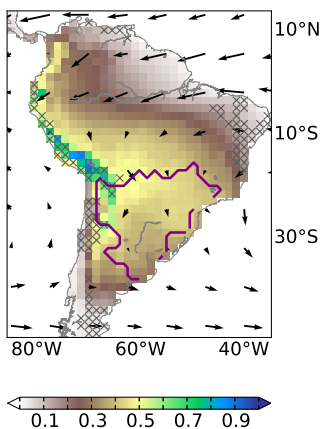

(i) $\rho_{c}$

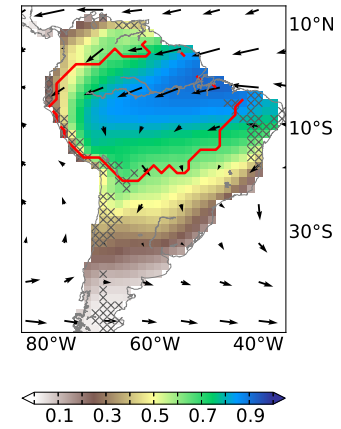

(j) $\varepsilon_{c}$

Figure 1. WAM-2layers input and output as calculated for the period 2001-2010 for MODIS and TRMM (input MOD; see Table 1): long-term seasonal mean of precipitation $(\mathbf{a}, \mathbf{f})$, evapotranspiration $(\mathbf{b}, \mathbf{g})$, precipitation-evapotranspiration $(\mathbf{c}, \mathbf{h})$, continental precipitation recycling ratio $\rho_{\mathrm{c}}(\mathbf{d}, \mathbf{i})$ and continental evapotranspiration recycling ratio $\varepsilon_{\mathbf{c}}(\mathbf{e}, \mathbf{j})$ indicating respective sinks and sources of continental moisture. Here and in the following figures, the vectors indicate the horizontal moisture flux field (in $\mathrm{m}^{3}$ of moisture $\times \mathrm{m}^{-2} \times \mathrm{month}^{-1}$ ) and the hatches represent grid cells where mean annual evapotranspiration exceeds mean annual precipitation. The red lines delimit the Amazon basin and the purple lines delimit the La Plata basin. Results are given for the dry season (upper row) and the wet season (lower row).

matology Centre (GPCC) (Huffman et al., 1995; Adler et al., 2003), the Global Precipitation Climatology Project (GPCP) (Adler et al., 2003) and the unified climate prediction center (CPC) from the National Oceanic and Atmospheric Administration (NOAA) (Chen et al., 2008). The four precipitation data sets are interpolations from rain gauge data (in combination with satellite observation in the case of GPCC) and have been considered as the forcing data set for the observation-based evapotranspiration product in LandFluxEVAL (Mueller et al., 2013). Here, we include the evapotranspiration products in LandFlux-EVAL that are not only derived from observations but also calculated via land surface models and output from reanalysis.

Both data sets are complemented by 6-hourly specific humidity and wind speed in three dimensions from the ERAInterim reanalysis product (Dee et al., 2011) for the corresponding periods. Because these two variables are used to get the horizontal moisture fluxes, the choice of the reanalysis product matters for the eventual results of the WAM-2layers (Keys et al., 2014). Humidity estimation has been improved in the ERA-Interim product in comparison with other reanalysis products (Dee and Uppala, 2008).

The temporal resolution of the input data needed in WAM2layers is $3 \mathrm{~h}$. Therefore, we downscaled the input MOD and LFE based on the temporal dynamics found in the ERAInterim evapotranspiration and precipitation products. In addition, all data are downscaled to $0.5 \mathrm{~h}$ as requested by the numerical scheme of WAM-2layers. All data are upscaled to a regular grid of $1.5^{\circ}$ longitude-latitude and cover the South American continent to $50^{\circ} \mathrm{S}$, which is the southernmost latitude covered by the TRMM product.

The long-term seasonal average of evapotranspiration and precipitation as well as moisture flux divergence (evapotranspiration-precipitation) are shown in Figs. 1 and 2. The high rainfall in the South Atlantic Convergence Zone (including the Amazon basin, central and south-eastern 
Input LFE, dry season (JJAS)

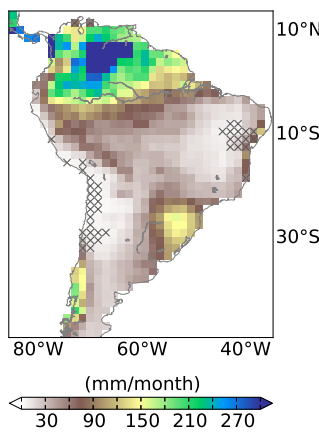

(a) Precip.

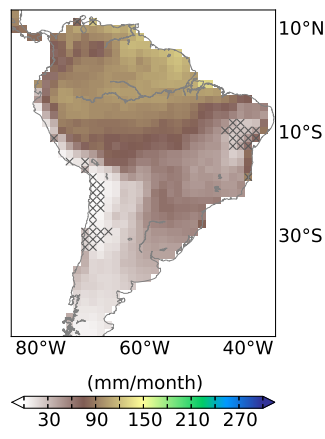

(b) Evap.

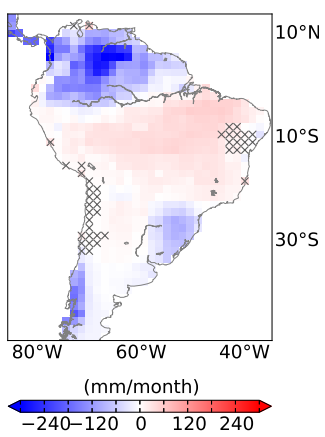

(c) Evap. - Precip.

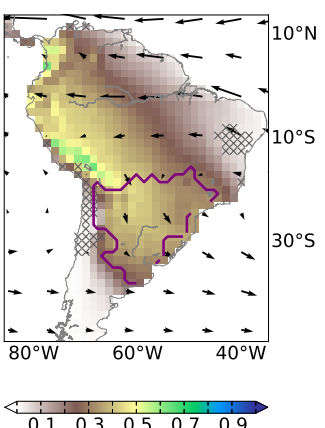

(d) $\rho_{c}$

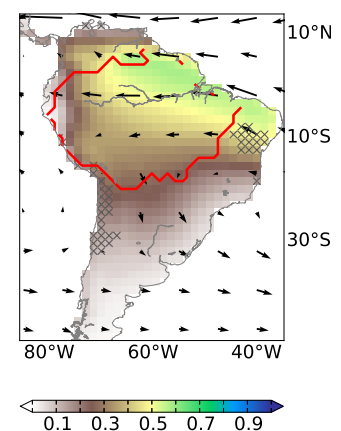

(e) $\varepsilon_{c}$

Input LFE, wet season (DJFM)

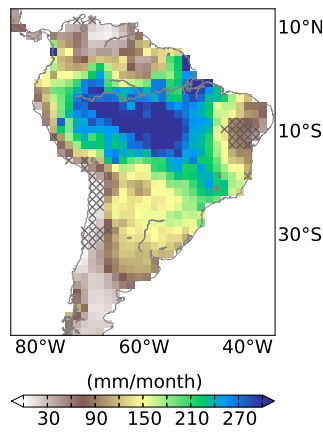

(f) Precip.

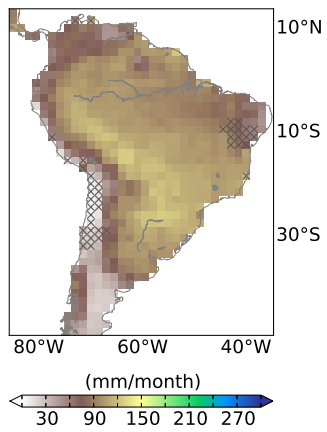

(g) Evap.

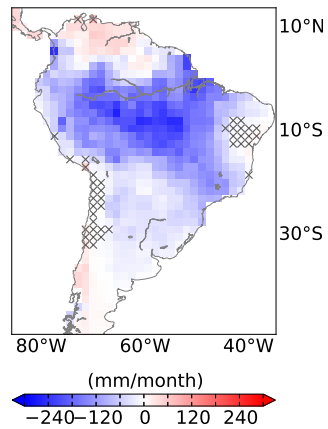

(h) Evap. - Precip.

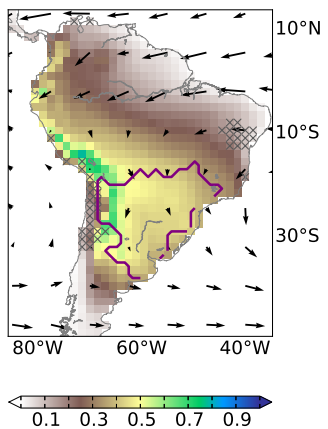

(i) $\rho_{c}$

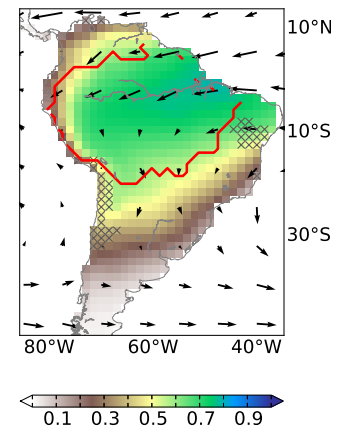

(j) $\varepsilon_{c}$

Figure 2. Same as Fig. 1 for the period 1990-1995 as calculated from LandFlux-EVAL and an average of four observation-based precipitation products (input LFE; see Table 1).

Brazil) during the wet season (December to March) compared to the dry season (June to September) characterizes the South American monsoon system (SAMS) (Liebman et al., 1999; Grimm et al., 2004; Arraut and Satyamurty, 2009).

The evapotranspiration and precipitation in the input MOD have an overall positive bias compared to the input LFE. While the spatial patterns of evapotranspiration show good agreement on a continental scale, there are also several distinct differences. In particular the wet season evapotranspiration in sub-tropical South America is much weaker in the input MOD then LFE. Interpreting and explaining the differences between the data sets is beyond the scope of this study. For an evaluation of the different types of products (model calculation, observation-based and reanalysis), we refer the reader to Mueller et al. (2011).

In both inputs, the evapotranspiration exceeds the total precipitation in the southern part of the Amazon basin during the dry season, indicating that this region is a net source of moisture for the atmosphere (Figs. 1c and 2c). This is in agreement with previous studies demonstrating a maintaining of the greenness of the Amazon forests (Morton et al., 2014) and the absence of water stress during the dry season due to the deep root system, which enables the pumping of the water from the deeper water table (Nepstad et al., 1994; Miguez-Macho and Fan, 2012).

We find that, averaged over the full time period, evapotranspiration exceeds precipitation in north-eastern Brazil and in the Atacama Desert in both data sets, as well as along the Andes in the input MOD. Possible explanations for the imbalance in these arid to semi-arid regions are irrigation or biases in the input data as mentioned above. As this might lead to a bias in moisture recycling ratios due to an overestimation of the contribution of evapotranspiration to local precipitation, we will exclude these grid cells from our analysis.

\subsubsection{Construction of a complex network based on WAM-2layers}

The output of WAM-2layers is a matrix $\mathbf{M}=\left\{m_{i j}\right\}$ for all $i, j \in N$ with $N$ the number of grid cells in the continent $(N=681)$. The non-diagonal element $m_{i j}$ gives the amount of evapotranspiration in grid cell $i$ that precipitates in grid cell $j$, and the diagonal element $m_{i i}$ is the amount of evapotranspiration that precipitates in the same grid cell (locally 
recycled moisture). The output of WAM-2layers can be interpreted as the adjacency matrix of a directed and weighted complex network with self-interactions, where nodes of the network represent continental grid cells and links between nodes represent the direction and amount of moisture transported between them (Fig. 3).

\subsection{Basic assumptions}

In order to track moisture forward or backward from a given region $(\Omega)$ that can be of any shape and scale (grid cell, basin, continent), we assume that the moisture composition within the surface reservoir and the atmosphere for each grid cell remains the same. This implies that, in each grid cell, the tagged fraction of precipitation is linearly proportional to the tagged fraction of evapotranspiration and the tagged fraction of transported moisture:

$\frac{P_{\Omega}}{P}=\frac{E_{\Omega}}{E}=\frac{m_{\Omega}}{m}$,

where $E$ is the total evapotranspiration, $P$ is the total precipitation, $m$ is the transported moisture towards or from another grid cell, $P_{\Omega}$ is the tagged fraction of precipitation, $E_{\Omega}$ is the tagged fraction of evapotranspiration and $m_{\Omega}$ is the tagged fraction of transported moisture towards or from another grid cell. We call tagged fraction the share of the moisture originating from $\Omega$ in the case of a backward tracking and the share of moisture precipitating over $\Omega$ in the case of a forward tracking.

This assumption is valid under two conditions: (1) evapotranspiration follows directly after the precipitation event or (2) the fraction of tagged moisture in the surface reservoir and the atmosphere can be assumed to be temporally constant (i.e., in steady state) (Goessling and Reick, 2013). The first condition is usually fulfilled during interception and fast transpiration, which are important components of the total evapotranspiration, particularly in warm climates and for shallow rooted plants (Savenije, 2004). However, in seasonal forests with deep rooted trees, the moisture that is evaporated during the dry season can be held back for several months (Savenije, 2004). By analyzing a seasonally static moisture recycling network, we account for this limitation. The second condition is fulfilled if the soil water at the beginning has the same composition (in terms of tagged fraction) as the atmospheric moisture at the end of the season.

\subsection{Moisture recycling ratio}

Common measures to quantify the strength of the direct link between precipitation in a specific location and evapotranspiration from another location are the moisture recycling ratios (called hereafter DMR ratio) (Eltahir and Bras, 1994; Trenberth, 1999; Bosilovich and Chern, 2006; Dirmeyer et al., 2009; van der Ent et al., 2010; Keys et al., 2012; Bagley et al., 2014). The DMR ratios are only used to investigate
DMR. Here, we further develop these measures in order to take CMR into account.

\subsubsection{Direct moisture recycling ratios}

Two kinds of DMR ratios have been developed in a previous study (van der Ent et al., 2010): the direct precipitation recycling ratio and the direct evapotranspiration recycling ratio. The direct precipitation recycling ratio $\left(\rho_{\Omega}\right)$ has been defined as the fraction of precipitation that is originating from evapotranspiration from a defined region $(\Omega)$ with no intervening re-evaporation cycle. The $\rho_{\Omega}$ for grid cell $j$ is calculated as

$\rho_{\Omega, j}=\frac{\sum_{i \in \Omega} m_{i j}}{P_{j}}$,

where $m_{i j}$ is the amount of evapotranspiration in $i$ that precipitates in $j$ with no intervening re-evaporation cycle and $P_{j}$ is the precipitation in $j$. We note that $\rho_{\Omega}$ averaged over all grid cells in $\Omega$ gives the regional recycling ratio, i.e, the fraction of precipitation that is regionally recycled (Eltahir and Bras, 1994; Burde et al., 2006; van der Ent and Savenije, 2011). High values of $\boldsymbol{\rho}_{\Omega}$ indicate the direct sink regions of evapotranspiration from $\Omega$, i.e., the regions that are dependent on evapotranspiration coming directly (i.e., through DMR) from $\Omega$ for local precipitation. A direct sink region receives moisture from $\Omega$ at first and might distribute it further downwind (Fig. 4).

Similarly, the direct evapotranspiration recycling ratio $\left(\boldsymbol{\varepsilon}_{\Omega}\right)$ has been defined as the fraction of evapotranspiration that falls as precipitation over a defined region $(\Omega)$ with no intervening re-evaporation cycle. The $\varepsilon_{\Omega}$ for grid cell $i$ is calculated as

$\varepsilon_{\Omega, i}=\frac{\sum_{j \in \Omega} m_{i j}}{E_{i}}$,

where $E_{i}$ is the evapotranspiration in $i$. High values indicate the direct source regions of precipitation over $\Omega$, i.e., the regions that contribute directly (i.e., through DMR) to rainfall over $\Omega$. A direct source region distributes moisture towards $\Omega$, which might be originating from further up-wind regions (Fig. 4).

If $\Omega$ is the entire South American continent, $\boldsymbol{\varepsilon}_{\Omega}$ becomes the continental evapotranspiration recycling ratio $\left(\varepsilon_{\mathrm{c}}\right)$ and $\rho_{\Omega}$ the continental precipitation recycling ratios $\left(\rho_{\mathbf{c}}\right)$ as defined in van der Ent et al. (2010). Considered together, $\boldsymbol{\varepsilon}_{\mathrm{c}}$ and $\rho_{\mathbf{c}}$ indicate sources and sinks of continental moisture, respectively. In this study we neglect possible contributions of moisture in South America from and to other continents, since these contributions to the overall moisture budget are small (van der Ent et al., 2010, Table 2). However, below we omit the area-weighting from the formulae for clarity..

\subsubsection{Cascading moisture recycling ratios}

We define the cascading precipitation recycling ratio $\left(\rho_{\Omega}^{\text {casc }}\right)$ as the fraction of precipitation that is originating from evap- 

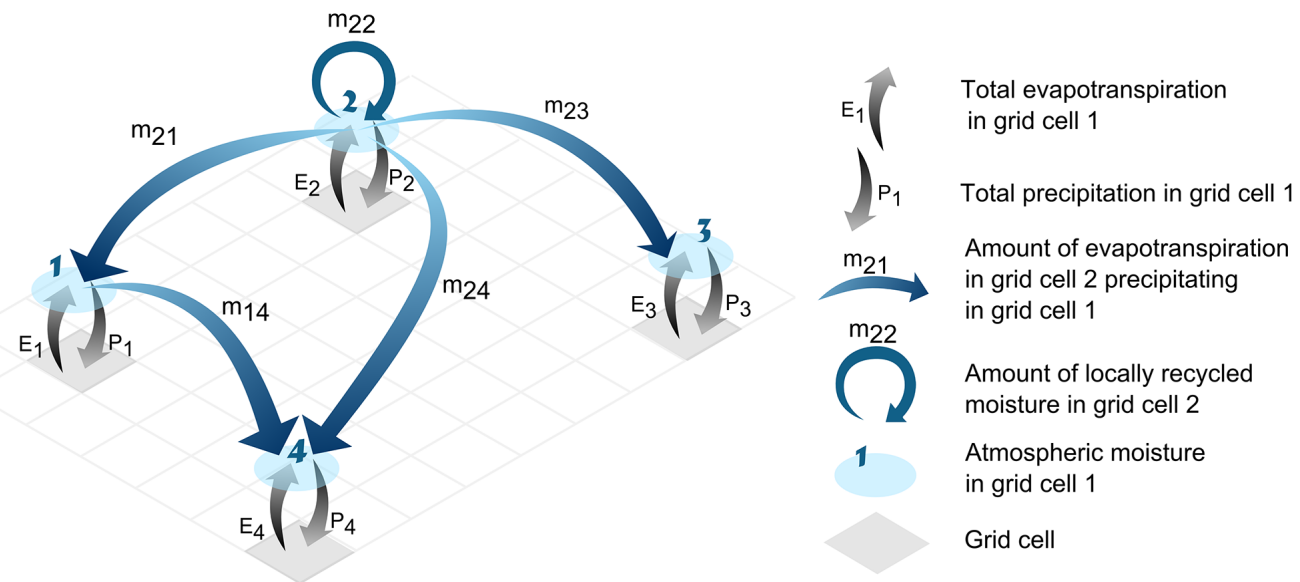

Figure 3. Schematic representation of the moisture recycling network. The exchange of moisture from 2 to 4 uses two alternative pathways: the direct one $\left(m_{24}\right)$ and the cascading pathway $\left(m_{21} m_{14}\right)$. The grid cell 1 is an intermediary on an alternative pathway to the direct transport of moisture between 2 and 4 . Thus, grid cell 1 forms a Middleman motif with grid cells 2 and 4 .

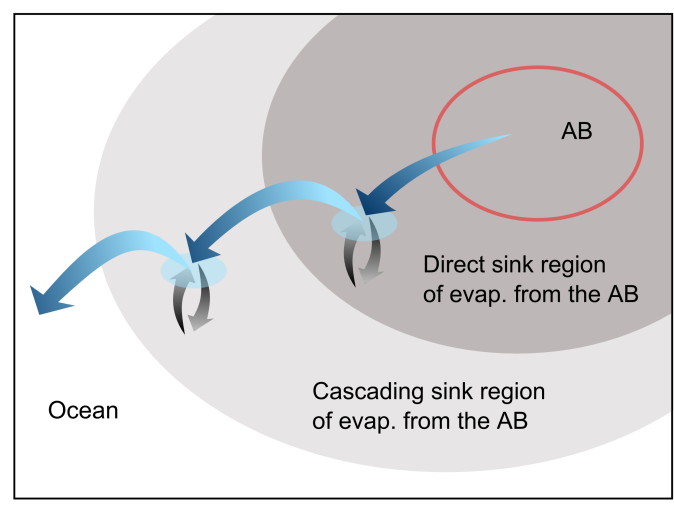

(a)

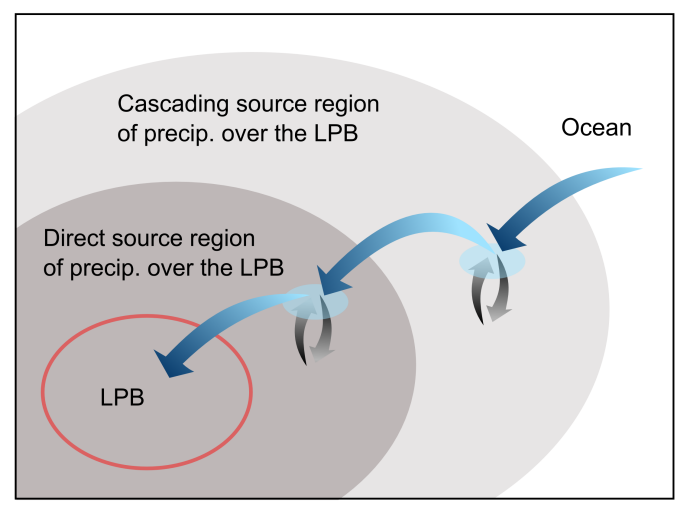

(b)

Figure 4. Schematic representation of the sink and source regions as quantified by the moisture recycling ratios. In addition to the direct source and sink regions identified using DMR ratios (dark gray), the cascading source and sink regions identified using CMR ratios (light gray) are highlighted. Of specific interest for this study are: direct and cascading sink regions of evapotranspiration (evap.) from the Amazon basin (AB) (a) and direct and cascading source regions of precipitation (precip.) over the La Plata basin (LPB) (b).

otranspiration from $\Omega$ and that has run through at least one re-evaporation cycle on the way. High values indicate the cascading sink regions of evapotranspiration from $\Omega$, i.e., the regions that are dependent on evapotranspiration coming indirectly (i.e., through CMR) from $\Omega$ for local precipitation. A cascading sink region is the last destination of evapotranspiration from $\Omega$ before it is advected over the ocean (Fig. 4).

We also define the cascading evapotranspiration recycling ratio $\left(\varepsilon_{\Omega}^{\text {casc }}\right)$ as the fraction of evapotranspiration that falls as precipitation over $\Omega$ after at least one re-evaporation cycle on the way. High values indicate the cascading source regions of precipitation over $\Omega$, i.e., the regions that contribute indirectly (i.e., through CMR) to rainfall over $\Omega$. A cascading source region is the origin of moisture that is distributed from somewhere else towards $\Omega$ (Fig. 4).
The moisture inflow (outflow) that crosses the border of $\Omega$ may be counted several times as it is involved in several pathways of CMR. To avoid this, we only track moisture that crosses the border of $\Omega$. This implies that we consider reevaporation cycles outside $\Omega$ only (Fig. 4). For a complete description of the methodology, we refer the reader to Appendix B1.

\subsubsection{Application to the Amazon basin and the La Plata basin}

To study the moisture recycling between the Amazon basin (defined by the red boundaries in Fig. 1e) and the La Plata basin (defined by the purple boundaries in Fig. 1d), we use $\rho_{\Omega}$ and $\rho_{\Omega}^{\text {casc }}$ with $\Omega$ being all grid cells covering the Amazon basin $\left(\rho_{\mathrm{Am}}\right.$ and $\rho_{\mathrm{Am}}^{\text {casc }}$, respectively) and $\boldsymbol{\varepsilon}_{\Omega}$ and $\boldsymbol{\varepsilon}_{\Omega}^{\text {casc }}$ with 
Table 2. Overview of regional precipitation recycling ratio in the Amazon basin as found in many studies. Abbreviations: the European Centre for Medium-Range Weather Forecasts (ECMWF); Geophysical Fluid Dynamics Laboratory (GFDL); Climate Prediction Center Merged Analysis of Precipitation (CMAP); initial conditions (IC); October-November-December (OND); Data Assimilation Office (DAO); integral moisture balance (IMB); National Centers for Environmental Prediction (NCEP) - Department of Energy (DOE); World Monthly Surface Station Climatology distributed by the National Center for Atmospheric Research (NCAR).

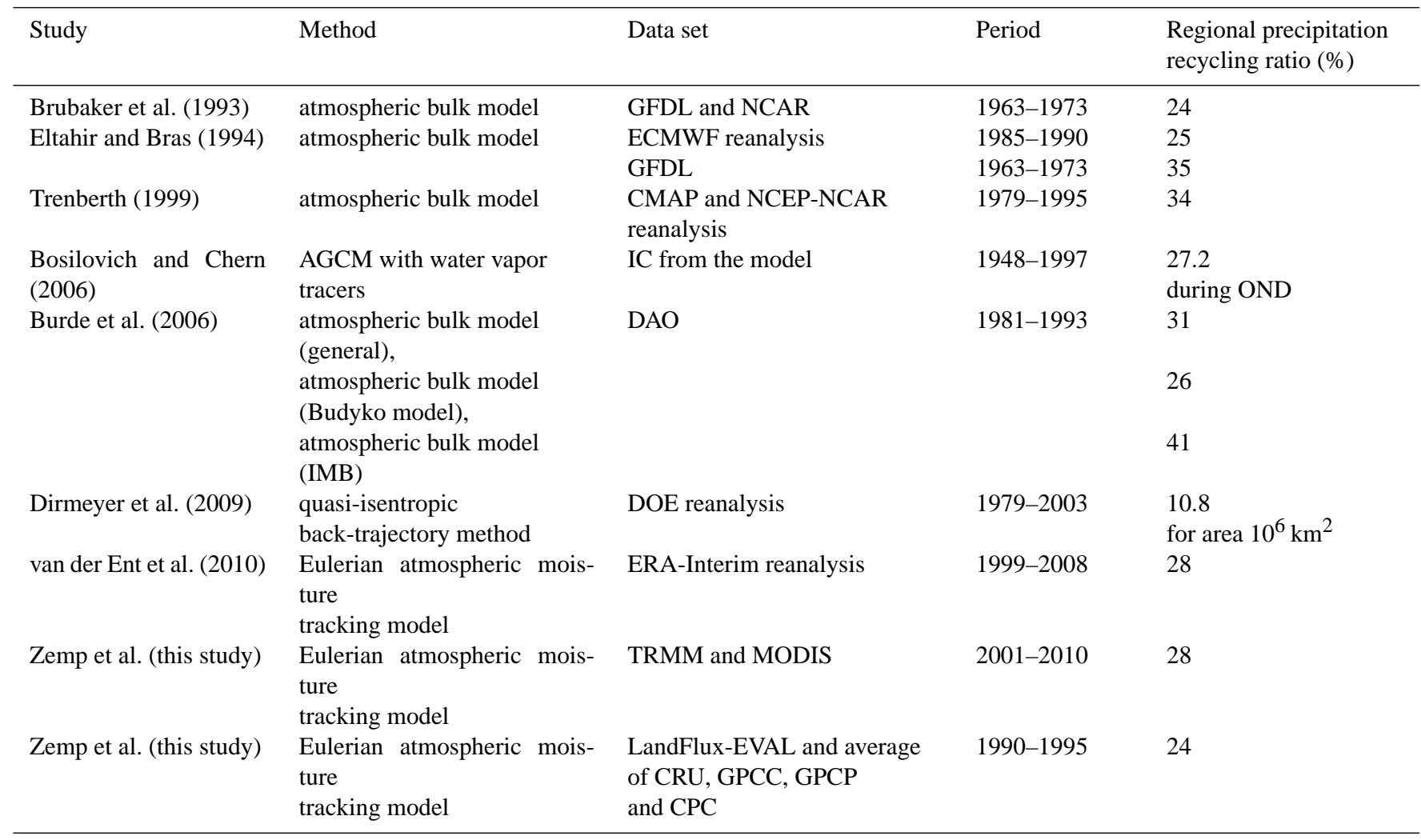

$\Omega$ being all grid cells covering the La Plata basin $\left(\varepsilon_{\mathrm{Pl}}\right.$ and $\boldsymbol{\varepsilon}_{\mathrm{Pl}}^{\text {casc }}$, respectively). High values of $\boldsymbol{\rho}_{\mathrm{Am}}$ and $\boldsymbol{\rho}_{\mathrm{Am}}^{\text {casc }}$ indicate together the sink regions of evapotranspiration from the Amazon basin and high values of $\varepsilon_{\mathrm{Pl}}$ and $\varepsilon_{\mathrm{Pl}}^{\text {casc }}$ highlight source regions of precipitation over the La Plata basin (Fig. 4).

Considered together, the DMR ratios and the CMR ratios provide a full picture of the source-sink relationship between the Amazon basin and the La Plata basin that is needed to estimate the effects of land use change for downwind precipitation patterns. $\boldsymbol{\rho}_{\mathrm{Am}}^{\text {casc }}$ and $\boldsymbol{\rho}_{\mathrm{Am}}$ quantify the local dependency on incoming moisture from the Amazon basin (with and without re-evaporation cycles) and therefore the local vulnerability to deforestation in the Amazonian rainforests. Considering $\rho_{\text {Am }}$ only would lead to underestimation of this dependency. On the other hand, $\boldsymbol{\varepsilon}_{\mathrm{Pl}}$ and $\boldsymbol{\varepsilon}_{\mathrm{Pl}}^{\text {casc }}$ provide information on the upwind regions that contribute to rainfall over the La Plata basin and, consequently, that should be preserved from intensive land use change in order to sustain water availability in the La Plata basin.

\subsection{Quantifying cascading moisture recycling}

To quantify the importance of CMR for the total moisture inflow (precipitation, $\boldsymbol{P}$ ) and outflow (evapotranspiration, $\boldsymbol{E})$, we cut off all re-evaporation of moisture originating from the continent and we estimate the resulting reduction in total moisture inflow $\left(\Delta \boldsymbol{P}_{\mathbf{c}}\right)$ and outflow $\left(\Delta \boldsymbol{E}_{\mathbf{c}}\right.$; see Appendix B3 for further information on the methodology). $\Delta \boldsymbol{P}_{\mathbf{c}} / \boldsymbol{P}$ is the fraction of precipitation that comes from reevaporation of moisture originating from the continent, i.e., that has been evaporated in at least two locations on the continent. $\Delta \boldsymbol{P}_{\mathbf{c}} / \boldsymbol{P}$ quantifies the importance of CMR for local rainfall. $\Delta \boldsymbol{E}_{\mathbf{c}} / \boldsymbol{E}$ is the fraction of total evapotranspiration that is a re-evaporation of moisture originating from the continent and that further precipitates over the continent, i.e., that lies within CMR pathways. $\Delta \boldsymbol{E}_{\mathbf{c}} / \boldsymbol{E}$ quantifies the local contribution to CMR. High values of $\Delta \boldsymbol{E}_{\mathbf{c}} / \boldsymbol{E}$ indicate intermediary regions. Regions that have a larger $\Delta \boldsymbol{E}_{\mathbf{c}} / \boldsymbol{E}$ than the 80th percentile (calculated for all continental values in each seasonal network) are called intermediary regions in the following. 
In addition, we are interested in the importance of reevaporation cycles that are occurring in the intermediary regions for the total moisture in- and outflow. We use the same approach as above. We cut off all re-evaporation in the intermediary region of moisture originating from the continent and we estimate the resulting reduction in total moisture inflow $\left(\Delta \boldsymbol{P}_{\mathbf{m}}\right)$ (see Appendix B3). $\Delta \boldsymbol{P}_{\mathbf{m}} / \boldsymbol{P}$ is the fraction of total moisture inflow that comes from CMR in the intermediary region (i.e., that has run through at least one re-evaporation cycle in the intermediary region). It quantifies the dependency on CMR in the intermediary region for local rainfall.

\subsection{Complex network analysis}

We investigate important moisture recycling pathways using two measures from complex network analysis: clustering coefficient associated with Middleman motifs and betweenness centrality.

\subsubsection{Clustering coefficient associated with Middleman motifs $(\tilde{\boldsymbol{C}})$}

In complex network theory, motifs are defined as significant and recurring patterns of interconnections that occur in the network (Milo et al., 2002). Here, we are interested in a particular pattern of directed triangles: the Middleman motif (Fagiolo, 2007). In our study, a grid cell forms a Middleman motif if it represents an intermediary on an alternative pathway to the direct transport of moisture between two other grid cells (Fig. 3).

The clustering coefficient is a measure from complex network analysis that measures the tendency to form a particular motif (Fagiolo, 2007). Here, it reveals intermediary locations in CMR pathways, as the alternative to the DMR between sources and sinks. To account for moisture fluxes along the network links, we compute the weighted version of the clustering coefficient associated with Middleman motifs $(\widetilde{\boldsymbol{C}})(\mathrm{Fa}-$ giolo, 2007; Zemp et al., 2014) for each grid cell as described in the Appendix B4.1.

A grid cell has a high $\widetilde{\boldsymbol{C}}$ if it forms a lot of Middleman motifs and if these motifs contribute largely to relative moisture transport. $\widetilde{\boldsymbol{C}}$ is equal to zero if the grid cell forms no Middleman motif at all.

It is worth to note that the Middleman motif considers three interconnected grid cells, which corresponds to CMR pathways involving only one re-evaporation cycle. These pathways usually contribute most to moisture transport between two locations. In fact, the amount of moisture transported in a pathway typically decreases with the number of re-evaporation cycles involved in the pathway. This is in agreement with a previous study counting the number of reevaporation cycles using a different methodology (Goessling and Reick, 2013). Other motifs formed by three grid cells linked by moisture recycling have been used to highlight dif- ferent patterns in moisture transport (e.g., cycle, integration and distribution) (Zemp et al., 2014), but are not analyzed here.

\subsubsection{Betweenness centrality $(B)$}

$\boldsymbol{B}$ aims to highlight nodes in the network with central position "to the degree that they stand between others and can therefore facilitate, impede or bias the transmission of messages" in the network (Freeman, 1977, p. 36). Here, we use it to reveal intermediary grid cells where CMR pathways are channeled.

To compute it, we first identify for each pair of grid cells the moisture recycling pathways with the greatest throughput, called optimal pathways (see methodology in Appendix B4.2). These pathways can include any number of re-evaporation cycles. As the optimal pathway is usually the direct one (without any re-evaporation cycle), we first had to modify the network such that the optimal pathways involve re-evaporation cycles. To do so, we removed from the network all long-range moisture transport, i.e., occurring over distances larger than 15 geographical degrees. The choice of this threshold does not influence the results qualitatively on a yearly basis (Fig. B3). During the dry season, removing longrange moisture transport affects moisture inflow over the $\mathrm{La}$ Plata basin; therefore, the results of the $\boldsymbol{B}$ will be interpreted with caution during this season.

Once optimal pathways are identified, we find intermediary grid cells that they have in common (see Appendix B4.3). A grid cell has a high $\boldsymbol{B}$ if many optimal pathways pass through it: moisture runs often through re-evaporation cycles in the grid cell. It has a $\boldsymbol{B}$ equal to 0 if none of these pathways pass through it: i.e., moisture never runs through re-evaporation cycles in the grid cell.

\subsection{Similarities and differences between the presented measures}

We expect similar spatial patterns in the results of $\Delta \boldsymbol{E}_{\mathrm{c}} / \boldsymbol{E}$ (fraction of evapotranspiration that lies within CMR pathways; see Sect. 2.4), the $\boldsymbol{B}$ (betweenness centrality; see Sect. 2.5.2) and the $\widetilde{\boldsymbol{C}}$ (clustering coefficient, Sect. 2.5.1). In fact, all three measures reveal important intermediary grid cells in CMR pathways. However, the three measures are based on different concepts and methods.

1. While $\Delta \boldsymbol{E}_{\mathrm{c}} / \boldsymbol{E}$ is calculated by inhibiting reevaporation of moisture from continental origin $\boldsymbol{B}$ is based on the notion of optimal pathways and $\widetilde{\boldsymbol{C}}$ relies on particular motifs formed by three connected grid cells.

2. An implication of (1) is that $\Delta \boldsymbol{E}_{\mathrm{c}} / \boldsymbol{E}$ quantifies the local contribution to CMR, $\widetilde{\boldsymbol{C}}$ refers to CMR pathways as alternative to the direct transport of moisture between two 
Table 3. Importance of direct moisture recycling (DMR) and cascading moisture recycling (CMR) for the total precipitation (precip.) and evapotranspiration (evap.) averaged for the La Plata basin (LPB), the Amazon basin (AB) and for the South American continent during the wet season (DJFM), the dry season (JJAS) and all year round calculated for the input MOD / LFE (in \%).

\begin{tabular}{|c|c|c|c|c|c|c|c|c|c|c|}
\hline \multirow[t]{2}{*}{ Notation } & \multirow[t]{2}{*}{ Description } & \multicolumn{3}{|c|}{ La Plata basin } & \multicolumn{3}{|c|}{ Amazon basin } & \multicolumn{3}{|c|}{ South America } \\
\hline & & wet & dry & year & wet & dry & year & wet & dry & year \\
\hline$\rho_{\mathrm{c}}$ & $\begin{array}{l}\text { fraction of precip. originat- } \\
\text { ing from the continent }\end{array}$ & $42 / 45$ & 35 / 35 & $41 / 43$ & $30 / 27$ & $35 / 30$ & $32 / 29$ & $30 / 29$ & $29 / 26$ & $31 / 29$ \\
\hline$\rho_{\mathrm{Am}}$ & $\begin{array}{l}\text { fraction of precip. originat- } \\
\text { ing from the } A B \text { through } \\
D M R\end{array}$ & $23 / 18$ & 25 / 21 & $24 / 20$ & $26 / 22$ & $30 / 25$ & $28 / 24$ & $18 / 15$ & $21 / 18$ & $20 / 17$ \\
\hline$\rho_{\mathrm{Am}}^{\operatorname{casc}}$ & $\begin{array}{l}\text { fraction of precip. originat- } \\
\text { ing from the } A B \text { through } \\
\text { CMR }\end{array}$ & $6 / 6$ & $2 / 3$ & $4 / 6$ & $-1-$ & $-/-$ & $-1-$ & $11 / 9$ & $6 / 6$ & $8 / 8$ \\
\hline$\varepsilon_{\mathrm{c}}$ & $\begin{array}{l}\text { fraction of evap. that falls as } \\
\text { precip. over the continent }\end{array}$ & $43 / 40$ & $16 / 16$ & 35 / 32 & 77 / 68 & 45 / 41 & $65 / 57$ & $56 / 29$ & $31 / 28$ & $47 / 42$ \\
\hline$\varepsilon_{\mathrm{Pl}}$ & $\begin{array}{l}\text { fraction of evap. that falls } \\
\text { as precip. over the LPB } \\
\text { through DMR }\end{array}$ & $32 / 28$ & $12 / 11$ & $26 / 22$ & $16 / 11$ & $7 / 6$ & $11 / 10$ & $15 / 13$ & $7 / 6$ & $12 / 11$ \\
\hline$\varepsilon_{\mathrm{Pl}}^{\text {casc }}$ & $\begin{array}{l}\text { fraction of evap. that falls } \\
\text { as precip. over the LPB } \\
\text { through CMR }\end{array}$ & $-1-$ & $-1-$ & $-1-$ & $23 / 16$ & $1 / 2$ & $10 / 7$ & $13 / 8$ & $1 / 1$ & $6 / 4$ \\
\hline$\Delta P_{\mathrm{c}} / P$ & $\begin{array}{l}\text { fraction of precip. that } \\
\text { comes from CMR in the } \\
\text { continent }\end{array}$ & $17 / 18$ & $14 / 12$ & $17 / 17$ & $8 / 6$ & $11 / 8$ & $10 / 7$ & $10 / 9$ & $9 / 7$ & $10 / 9$ \\
\hline$\Delta P_{m} / P$ & $\begin{array}{l}\text { fraction of precip. that } \\
\text { comes from CMR in the } \\
\text { intermediary region }\end{array}$ & $9 / 9$ & $5 / 5$ & $8 / 9$ & $4 / 3$ & $6 / 4$ & $4 / 4$ & $4 / 4$ & $5 / 3$ & $4 / 4$ \\
\hline$\Delta E_{\mathrm{c}} / E$ & $\begin{array}{l}\text { fraction of evap. that lies } \\
\text { within CMR pathways }\end{array}$ & $11 / 13$ & $9 / 8$ & $9 / 11$ & $11 / 8$ & $23 / 15$ & $12 / 10$ & $13 / 9$ & $15 / 10$ & $10 / 8$ \\
\hline
\end{tabular}

locations and $\boldsymbol{B}$ shows locations where CMR pathways are channeled.

3. In the $\widetilde{\boldsymbol{C}}$, only CMR pathways with one re-evaporation cycle are considered. Using $\Delta \boldsymbol{E}_{\mathrm{c}} / \boldsymbol{E}$ and $\boldsymbol{B}$, all number of cycles are possible in the pathways.

4. Moisture recycling pathways involving long-range transport are not considered in the calculation of the $\boldsymbol{B}$.

For these reasons, $\Delta \boldsymbol{E}_{\mathbf{c}} / \boldsymbol{E}, \boldsymbol{B}$ and $\widetilde{\boldsymbol{C}}$ are complementary measures. There are also some similarities between the calculation of the cascading precipitation recycling ratio $\left(\rho_{\Omega}^{\text {casc }}\right)$ and $\Delta \boldsymbol{P}_{\mathbf{c}} / \boldsymbol{P}$, which are described in the Appendix B2.

\section{Results and discussion}

\subsection{Comparison of continental and regional moisture recycling ratios with other existing studies}

The main continental source of precipitation over South America is the Amazon basin, with large heterogeneity in time and space (Figs. 1e, $1 \mathrm{j}, 2 \mathrm{e}$ and $2 \mathrm{j}$ and Table 3 ). Around 70 to $80 \%$ of the evapotranspiration in the southern part of the Amazon basin falls as precipitation over the continent during the wet season but only 30 to $40 \%$ during the dry season. As the evapotranspiration in the Amazon basin is high and varies little in space and time (Figs. 1b, 1g, 2b and 2g), this observation indicates that during the dry season, a high amount of moisture from the southern part of the Amazon basin is advected out of the continent. Using a Lagrangian particle dispersion model, Drumond et al. (2014) also found a maximum contribution of moisture from the Amazon basin to the ocean during this period.

The main sink regions of moisture originating from the continent are the western part of the Amazon basin during the dry season, the south-western part of the basin during the wet season and the La Plata basin especially during the wet season (Figs. 1d, 1i, 2d and $2 \mathrm{~d}$ and Table 3). In fact, in the La Plata basin, 42 to $45 \%$ of the precipitation during the wet season and $35 \%$ during the dry season evaporated from the continent. This difference between seasons is explained by a weaker transport of oceanic moisture associated with the sub-tropical Atlantic high and by an intensification of the SALLJ that transports moisture in the meridional direction during this season (Marengo et al., 2004). The importance of continental moisture recycling in the La Plata basin during 
the wet season has been emphasized in previous studies (Drumond et al., 2008; Martinez et al., 2014). Despite this importance, we find that the ocean remains the main source of moisture over the La Plata basin in agreement with previous studies (Drumond et al., 2008, 2014; Arraut and Satyamurty, 2009). However, some other studies estimated a higher contribution of moisture from the continent to precipitation over the La Plata basin (van der Ent et al., 2010; Keys et al., 2012; Martinez et al., 2014).

There are uncertainties in the moisture recycling ratios depending on the quality of the data sets used, the assumptions made in the methods and the boundaries used to define the domain (for example in Brubaker et al., 1993, the Amazon region is represented by a rectangle). Considering these uncertainties, the regional precipitation recycling ratio in the Amazon basin compares well with previous studies using other data sets and methodologies (Table 2). The spatial patterns of continental moisture recycling ratios (Figs. 1d, 1i, 1e, $1 \mathrm{j}, 2 \mathrm{~d}, 2 \mathrm{i}, 2 \mathrm{e}$ and $2 \mathrm{j}$ ) are slightly different from those found by van der Ent et al. (2010)- see their Figs. 3 and 4, due to the differences in the versions of the model (here we use WAM-2layers) and the data sets used. The continental precipitation recycling ratio in the Amazon basin reaching 27 to $30 \%$ during the Southern Hemisphere summer is slightly below estimates of $36.4 \%$ found by Bosilovich and Chern (2006). The maps of DMR ratios (Fig. 8a, and c, e and g) are in good agreement with the regional recycling ratio reported in previous studies (Eltahir and Bras, 1994, Figs. 4 and 6; Burde et al., 2006, Figs. 2 and 8; Dirmeyer et al., 2009; see http://www.iges.org/wcr/, Moisture Sources by Basin).

We note that our analysis period from 2001 to 2010 (for the input MOD) includes two major droughts in the Amazon basin (Marengo et al., 2008; Lewis et al., 2011). Because the land-atmosphere coupling on the hydrological cycle increases during drought years (Bagley et al., 2014), this might influence the output of the atmospheric moisture tracking model used in this study. Analyzing these periods separately is ongoing research.

\subsection{Importance of cascading moisture recycling}

Continental moisture recycling is of crucial importance for South American precipitation patterns (Figs. 1 and 2). We now quantify this importance (Fig. 5).

The share of cascading moisture on total moisture inflow is on average 9-10\% in the South American continent (Table 3). Regions that are dependent on CMR for local rainfall (Fig. 5a, c, e and g) are also dominant sinks of moisture from the continent (Fig. 1d, 1i, 2d and 2i).

We note that CMR contributes more to the precipitation over the Amazon basin during the dry season (8-11\% on average, up to $25 \%$ in the western part) compared to the wet season (6-8\% on average). This is explained by the fact that during the dry season, moisture is mainly transported from the eastern to the western part of the Amazon basin
(Figs. 1 and 2). Our results show that during the dry season, this moisture transport involves re-evaporation cycles in the central part of the basin (blue boundaries in Fig. $5 \mathrm{~b}$ and f). In fact, $15-23 \%$ of the total evapotranspiration from the Amazon basin is involved in CMR during the dry season.

During the wet season, CMR plays also an important role as $17-18 \%$ of the total precipitation over the La Plata basin comes from CMR. The intermediary region where re-evaporation cycles are taking place is mainly the southwestern part of the Amazon basin (blue boundaries in Fig. 5d and $\mathrm{h}$ ). In this intermediary region, up to $35 \%$ of the total evapotranspiration is involved in CMR during the wet season. We note that the shape of the intermediary regions varies slightly among the two data sets during the wet season, probably explained by the differences in evapotranspiration patterns (Figs. $1 \mathrm{~g}$ and $2 \mathrm{~g}$ ).

In order to evaluate the importance of the intermediary region for rainfall over the La Plata basin, we quantify the share of the moisture inflow in the La Plata basin that has run through re-evaporation cycles in the intermediary regions. This share is $9 \%$ during the wet season and $5 \%$ during the dry season. These estimations represent about half of the share of total moisture inflow over the La Plata basin that comes from CMR during the wet season (Table 3). These results mean that the intermediary regions are important for cascading moisture transported towards the La Plata basin during the wet season. In Sect. 3.4, we reveal the direct and cascading sources of precipitation over the La Plata basin and we understand the seasonal variability.

The share of cascading moisture on the total moisture inflow reaches up to $35-50 \%$ on the eastern side of the central Andes, one of the most vulnerable biodiversity hotspots on Earth (Myers et al., 2000). However, this latter observation should be considered with caution due to the imbalance of the water cycle in this area, which might lead to an overestimation of the regional recycling process and an overestimation of the importance of cascading moisture recycling.

\subsection{Complex network analysis}

We have shown the importance of CMR for South American moisture transport (Fig. 5). Using the clustering coefficient associated with the Middleman motif $(\widetilde{\boldsymbol{C}})$, we are able to identify intermediary locations involved in cascading pathways as alternatives to the direct transport of moisture (Fig. 6a, c, e and g). These regions coincide with the intermediary regions identified with a different method (blue boundaries in Fig. 5). These results mean that the CMR pathways involving the intermediary regions are not the only pathways of moisture recycled from sources to sinks on the continent, but are complementing the direct transport of moisture over long distances.

The betweenness centrality $(\boldsymbol{B})$ reveals intermediary regions where CMR pathways are channeled. We note that regions with high $\boldsymbol{B}$ coincide with regions with high $\widetilde{\boldsymbol{C}}$ dur- 


\section{Dry season (JJAS)}

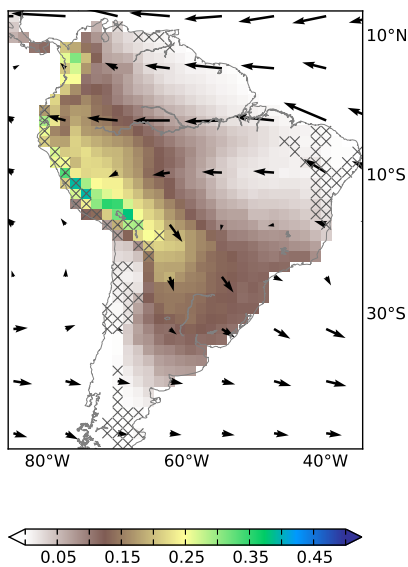

(a) $\Delta P_{c} / P$

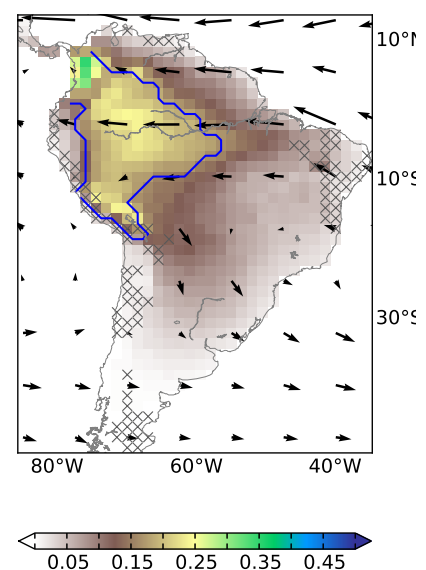

(b) $\Delta E_{c} / E$
Input MOD

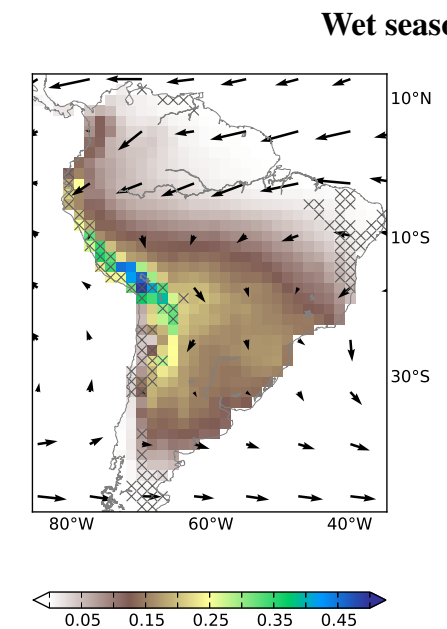

(c) $\Delta P_{c} / P$

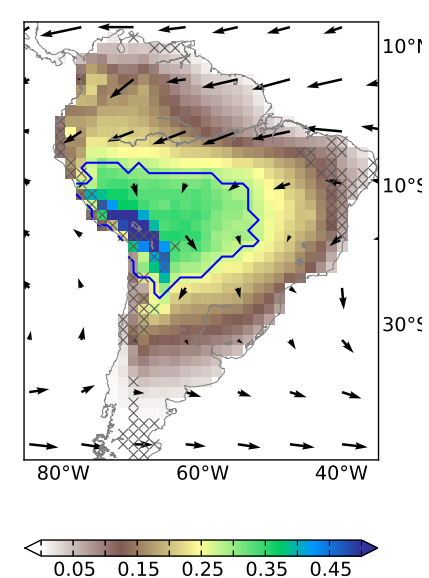

(d) $\Delta E_{c} / E$
Dry season (JJAS)

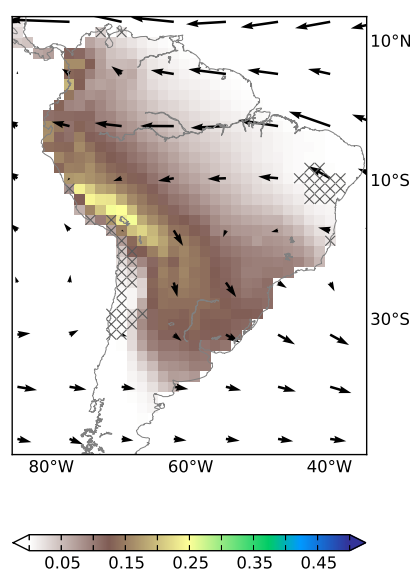

(e) $\Delta P_{c} / P$

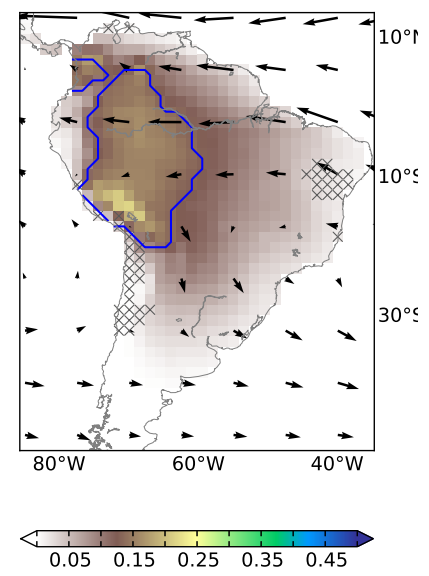

(f) $\Delta E_{c} / E$

Input LFE

Wet season (DJFM)

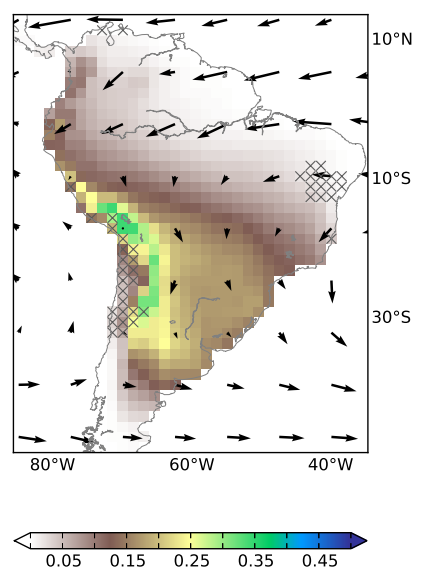

(g) $\Delta P_{c} / P$

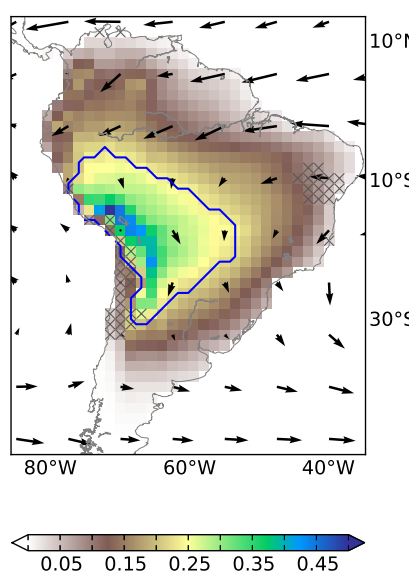

(h) $\Delta E_{c} / E$

Figure 5. Fraction of total precipitation originating from $\operatorname{CMR}\left(\Delta P_{\mathrm{c}} / P\right)(\mathbf{a}, \mathbf{c}, \mathbf{e}, \mathbf{g})$ and fraction of total evapotranspiration that lies within CMR pathways $\left(\Delta E_{\mathrm{c}} / E\right)(\mathbf{b}, \mathbf{d}, \mathbf{f}, \mathbf{h})$. While high values of $\Delta P_{\mathrm{c}} / P$ indicate regions that are dependent on CMR for local rainfall, high values of $\Delta E_{\mathrm{c}} / E$ indicate regions that contribute to CMR. The blue boundaries define the regions that have $\Delta E_{\mathrm{c}} / E>80$ percentile (calculated for all continental values in each seasonal moisture recycling network) and that are called intermediary regions. Results are obtained using the input MOD (upper row) and input LFE (lower row) (see Table 1) and are given for the dry season (left) and the wet season (right).

ing the wet season, but not as much during the dry season (Fig. 6). This might be a result of the cutting of long-range links from the network in the calculation of $B$, which affects moisture transport towards the sub-tropical South America during the dry season.

High values of $\boldsymbol{B}$ are found along a narrow band east of the sub-tropical Andes (Fig. 6d and h), indicating that CMR pathways are channeled in this region. This observation may be explained by the combined effect of the acceleration of the SALLJ (Vera et al., 2006) and the high precipitation and evapotranspiration during the wet season (Figs. 1 and 2) allowing for an intensive local exchange of moisture between the vegetation and the atmosphere.

\subsection{Moisture recycling from the Amazon basin to the La Plata basin}

We have shown the importance of the Amazon basin as the dominant source of continental moisture and the La Plata 


\section{Dry season (JJAS)}

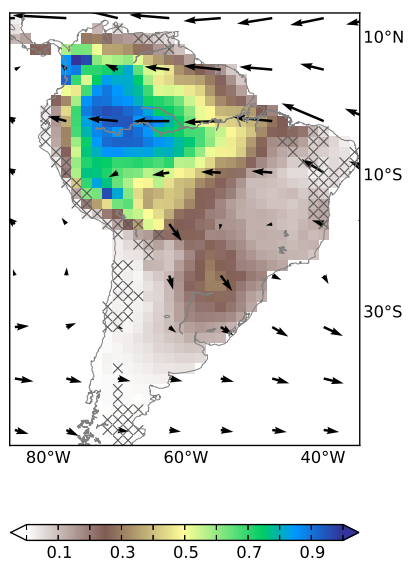

(a) $\tilde{C}$

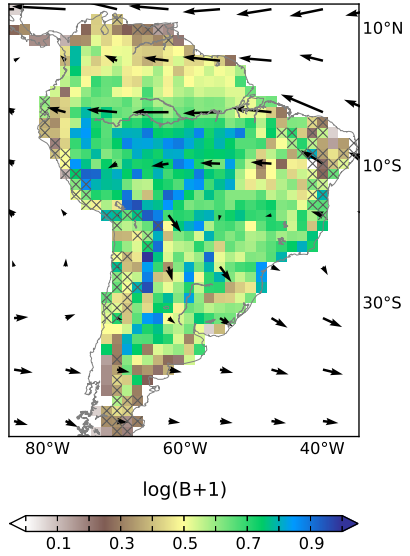

(b) $B$

\section{Input MOD}

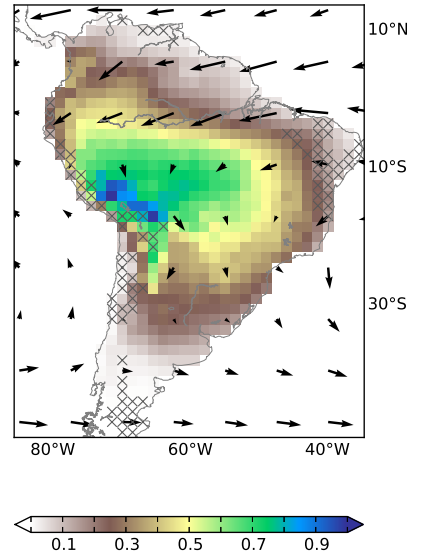

(c) $\tilde{C}$
Wet season (DJFM)

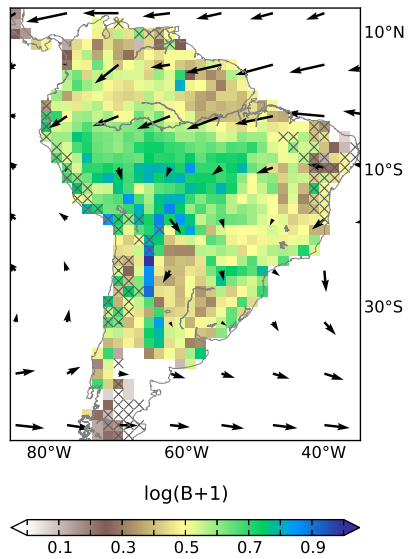

(d) $B$

Input LFE

Dry season (JJAS)

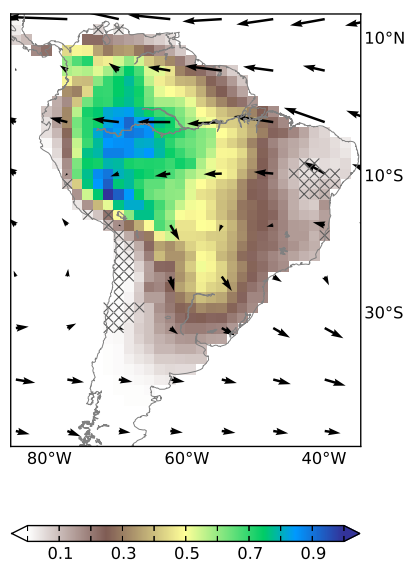

(e) $\tilde{C}$

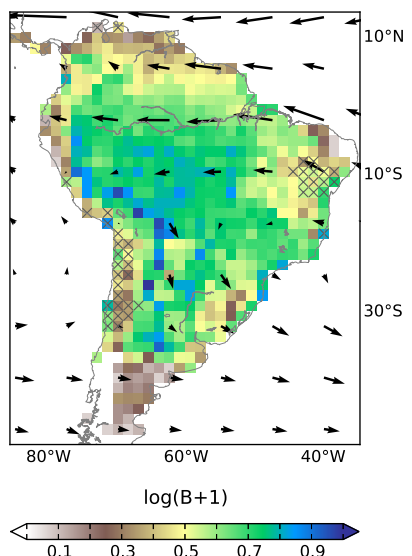

(f) $B$

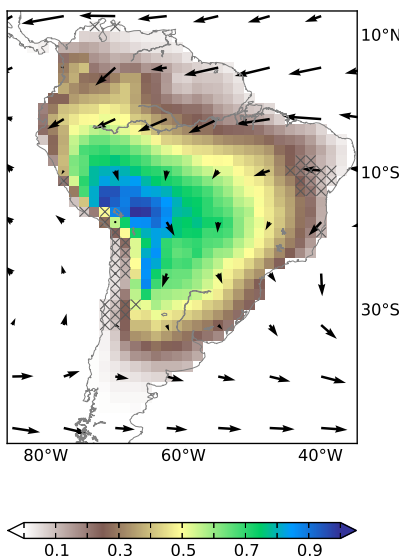

(g) $\tilde{C}$
Wet season (DJFM)

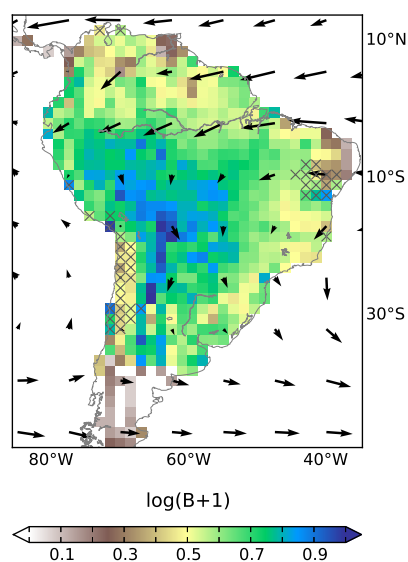

(h) $B$

Figure 6. Results of complex network analysis. Clustering coefficient $\widetilde{C}$ associated with the motif Middleman (a, c, e, g) and betweenness centrality $B(\mathbf{b}, \mathbf{d}, \mathbf{f}, \mathbf{h})$. While high values of $\widetilde{C}$ indicate intermediary locations where CMR allows for alternative pathways to the direct transport of moisture, high values of $B$ indicate regions where pathways of CMR are channeled. Results are obtained using the input MOD (upper row) and input LFE (lower row) (see Table 1) and are given for the dry season (left) and the wet season (right).

basin as a central sink region (see Figs. 1 and 2). In the following, we further investigate the importance of DMR and CMR for the transport of moisture between the two basins (Figs. 7 and 8).

In the La Plata basin, $18-23 \%$ of the precipitation during the wet season and $21-25 \%$ during the dry season originated from the Amazon basin with no intervening re-evaporation cycles (Table 3). This is in good agreement with the yearly average estimates of $23 \%$ found in Dirmeyer et al. (2009, see http://www.iges.org/wcr/) and $23.9 \%$ found in Martinez et al. (2014). However, these estimations take only DMR into account. Here, considering, considering CMR increases the fraction of precipitation over the La Plata basin that comes from the Amazon basin by $6 \%$ during the wet season (Table 3). As mentioned above, this might be explained by the high evapotranspiration and precipitation allowing for an exchange of moisture on the way and by the intensification of the SALLJ during this time of the year (Marengo et al., 2004). This result suggests that the impact of deforestation in the Amazonian forest on rainfall over the La Plata basin might be larger than expected if only direct transport of moisture between the two basins is considered.

The southern part of the Amazon basin is a direct source of precipitation over the La Plata basin (Fig. 7a, c, e and g). 
Dry season (JJAS)

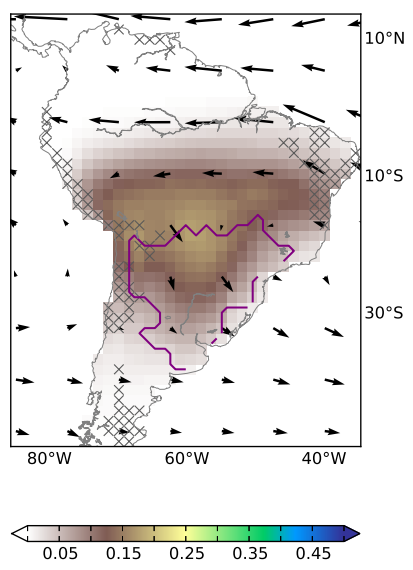

(a) $\varepsilon_{P l}$

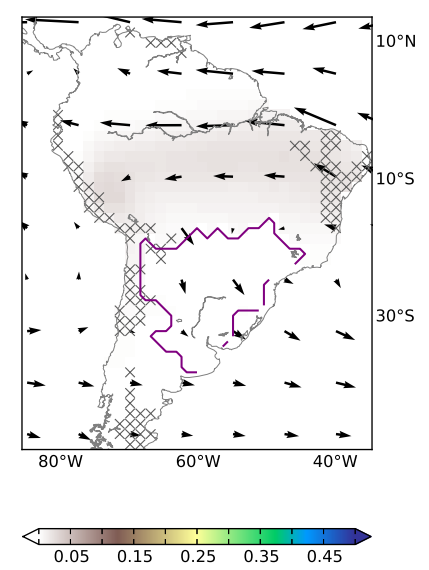

(b) $\varepsilon_{P l}^{c a s e}$

Input MOD

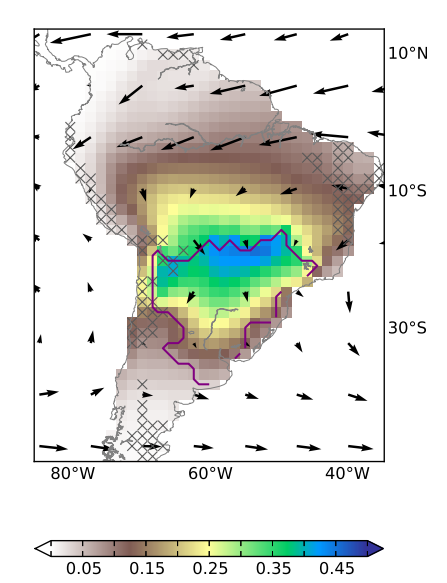

(c) $\varepsilon_{P l}$
Wet season (DJFM)

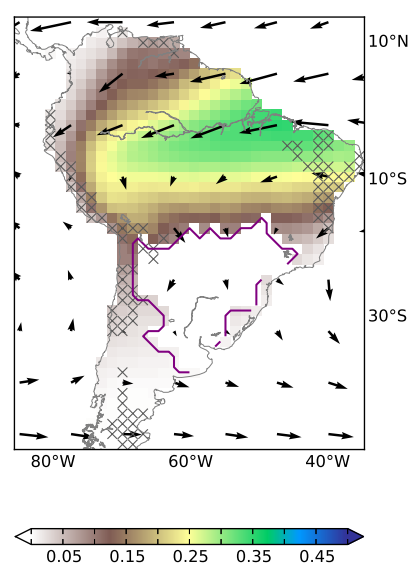

(d) $\varepsilon_{P l}^{c a s e}$

Input LFE

Dry season (JJAS)

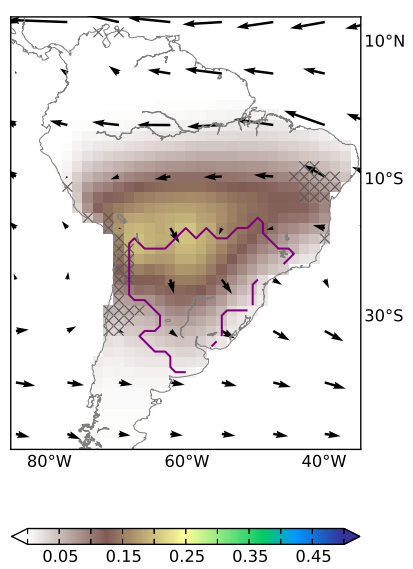

(e) $\varepsilon_{P l}$

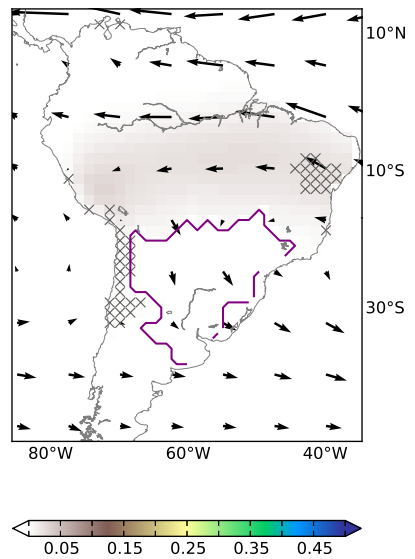

(f) $\varepsilon_{P l}^{c a s c}$

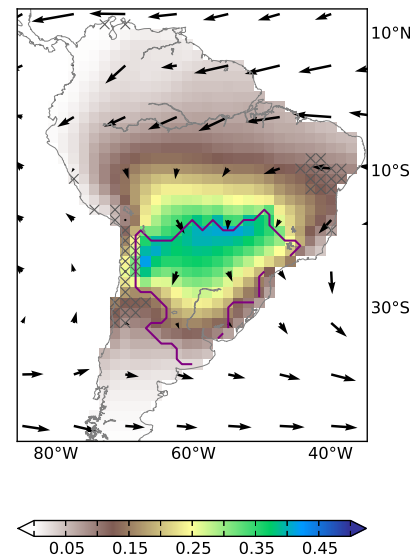

(g) $\varepsilon_{P l}$
Wet season (DJFM)

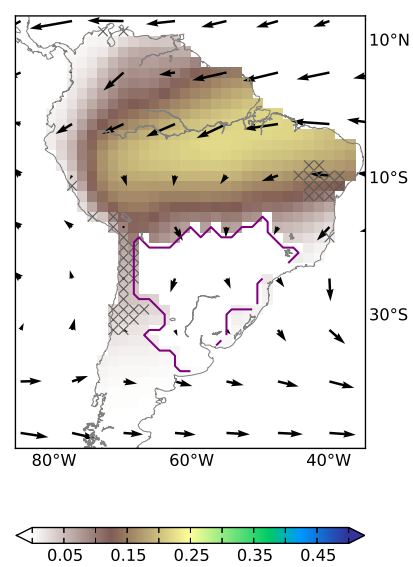

(h) $\varepsilon_{P l}^{c a s c}$

Figure 7. Fraction of evapotranspiration that precipitates over the La Plata basin (defined by the purple boundaries) through DMR ( $\varepsilon_{\mathrm{Pl}}, \mathbf{a}$, c, e and $\mathbf{g})$ and $\mathrm{CMR}\left(\varepsilon_{\mathrm{Pl}}^{\text {casc }}, \mathbf{b}, \mathbf{d}, \mathbf{f}\right.$ and $\left.\mathbf{h}\right)$. Considered together, $\varepsilon_{\mathrm{Pl}}$ and $\varepsilon_{\mathrm{Pl}}^{\text {casc }}$ show source regions of precipitation over the La Plata basin. Results are obtained using the input MOD (upper row) and input LFE (lower row) (see Table 1) and are given for the dry season (left) and the wet season (right).

This finding is in agreement with Martinez et al. (2014) and Keys et al. (2014). However, if CMR is considered, the entire Amazon basin becomes an evaporative source of moisture for the La Plata basin during the wet season (Fig. 7d and h). On average, $16-23 \%$ of the total evapotranspiration from the Amazon basin during the wet season ends as rainfall over the La Plata basin after at least one re-evaporation cycle (Table 3). This result means that during the wet season, the southern part of the Amazon basin is not only a direct source of moisture for the La Plata basin but also an intermediary region that distributes moisture originating from the entire basin. This finding is in agreement with other measures showing intermediary regions (Sects. 3.2 and 3.3).

\subsection{Possible impact of land-cover change in the intermediary regions}

The southern part of the Amazon basin is a key region for moisture transport towards the La Plata basin. It is a source of moisture for precipitation over the La Plata basin all year round. In addition, it is an intermediary region for the indirect transport of moisture (through CMR) originating from the entire Amazon basin during the wet season (Sect. 3.4). 
Dry season (JJAS)

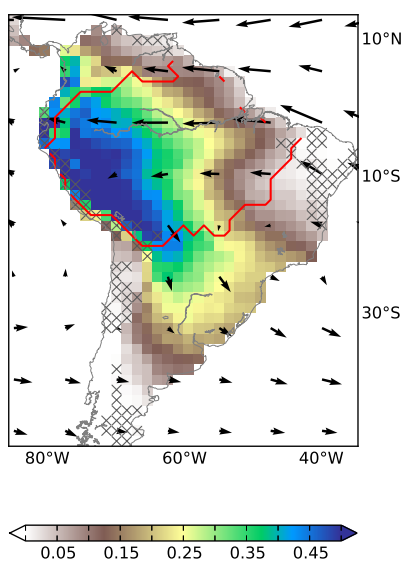

(a) $\rho_{A m}$

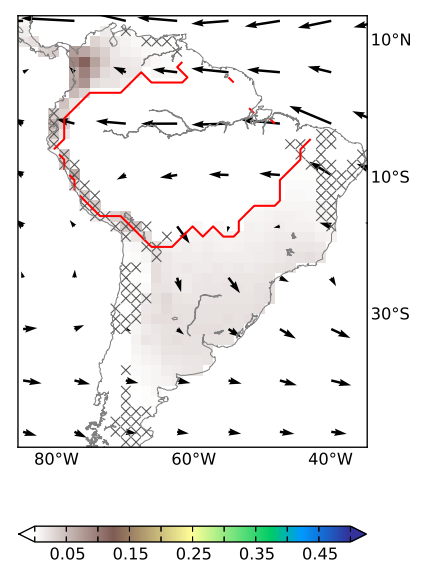

(b) $\rho_{A m}^{c a s c}$
Input MOD
Wet season (DJFM)

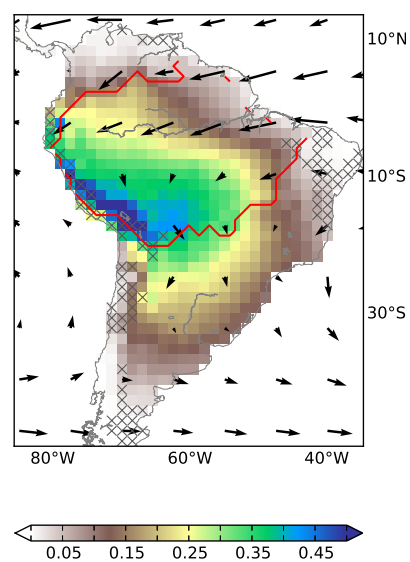

(c) $\rho_{A m}$
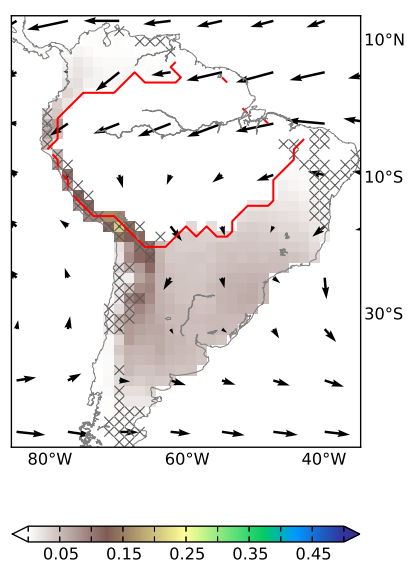

(d) $\rho_{A m}^{\text {casc }}$

Input LFE

Dry season (JJAS)
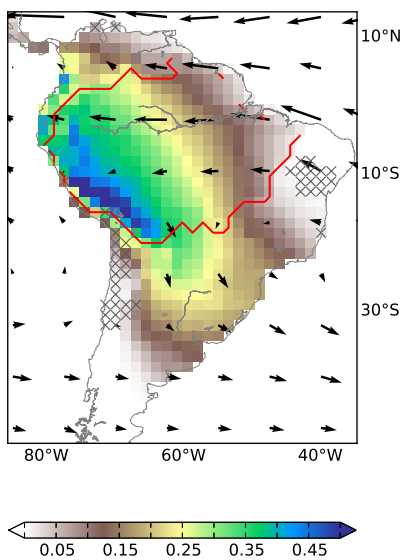

(e) $\rho_{A m}$

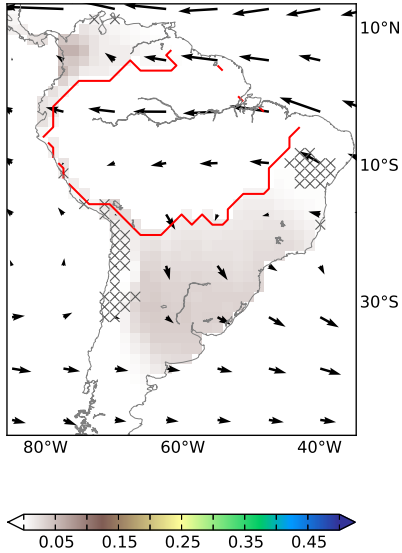

(f) $\rho_{A m}^{c a s c}$

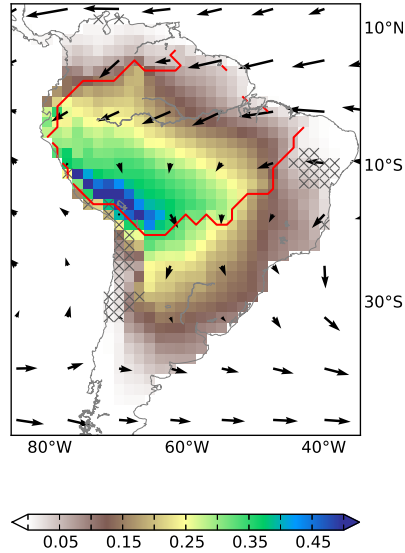

(g) $\rho_{A m}$
Wet season (DJFM)
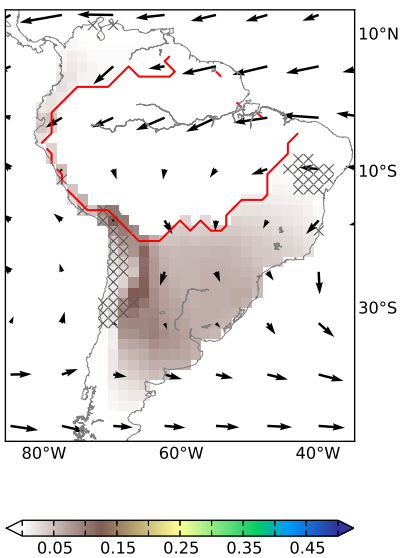

(h) $\rho_{A m}^{c a s c}$

Figure 8. Fraction of precipitation that originates from the Amazon basin (defined by the red boundaries) through DMR $\left(\rho_{\mathrm{Am}}, \mathbf{a}, \mathbf{c}, \mathbf{e}\right.$ and $\left.\mathbf{g}\right)$ and CMR ( $\rho_{\mathrm{Am}}^{\mathrm{casc}}, \mathbf{b}, \mathbf{d}, \mathbf{f}$ and $\left.\mathbf{h}\right)$. Considered together, $\rho_{\mathrm{Am}}$ and $\rho_{\mathrm{Am}}^{\mathrm{casc}}$ show sink regions of evapotranspiration from the La Plata basin. Results are obtained using the input MOD (upper row) and input LFE (lower row) (see Table 1) and are given for the dry season (left) and the wet season (right).

Land-cover change in the southern part of the Amazon basin might weaken continental moisture recycling and might lead to an substantial decrease in the total precipitation locally and downwind. Among the affected regions, important impacts would be observed in particular in the southwestern part of the Amazon basin that has already a high probability to experience a critical transition from forest to savanna (Hirota et al., 2011) and in the La Plata basin that is dependent on incoming rainfall for agriculture (Rockström et al., 2009; Keys et al., 2012). At the eastern side of the central Andes, the impact of an upwind weakening of CMR might be reduced since precipitation in this region is ensured by orographic lifting (Figueroa and Nobre, 1990).

\section{Conclusions}

In this work, we investigated the exchange of moisture between the vegetation and the atmosphere on the way between sources and sinks of continental moisture in South America. We have introduced the concept of cascading moisture recycling (CMR) to refer to moisture recycling between two locations on the continent that involve one or more re-evaporation cycles along the way. We have proposed measures to quan- 
tify the importance of CMR, to track moisture from a given region further backward or forward in space and to identify intermediary regions where re-evaporation cycles are taking place. We have used for the first time a complex network approach to study moisture recycling pathways.

We have tracked moisture evaporating from each grid cell covering the South American continent until it precipitates or leaves the continent using the Eulerian atmospheric moisture tracking model WAM-2layers (Water Accounting Modeltwo layers). In order to reduce the uncertainty associated with the input data, we have used two different sets of precipitation and evapotranspiration data from (1) observationbased and (2) merged synthesis products, together with reanalysis wind speeds and humidity data. We have shown that even if the amount of water transported through CMR pathways is typically smaller than the one transported directly in the atmosphere, the contribution by the ensemble of cascading pathways cannot be neglected. In fact, $9-10 \%$ of the total precipitation over South America, as well as $17-18 \%$ of the precipitation over the La Plata basin, comes from CMR. The La Plata basin is highly dependent on moisture from the Amazon basin during both seasons, as $18-23 \%$ of the total precipitation over the La Plata basin during the wet season, as well as $21-25 \%$ during the dry season, comes directly from the Amazon basin. To these direct dependencies, $6 \%$ of the precipitation during the wet season can be added if CMR is considered.
During the dry season, CMR plays an important role for the moisture transport from the eastern to the western part of the Amazon basin. Indeed, $15-23 \%$ of the total evapotranspiration in the Amazon basin is involved in CMR during the dry season.

The south-western part of the Amazon basin is an important direct source of incoming moisture over the La Plata basin all year round. However, during the wet season, it is not only a direct source but also an intermediary region that distributes moisture from the entire Amazon basin into the La Plata basin. Land use change in these regions may weaken moisture recycling processes and may have stronger consequences for rainfed agriculture and natural ecosystems regionally and downwind as previously thought.

In addition, we showed that the eastern flank of the subtropical Andes - located in the pathway of the South American low-level jet - plays an important role in the continental moisture recycling as it channels many cascading pathways. This study offers new methods to improve our understanding of vegetation and atmosphere interactions on the water cycle needed in a context of land use and climate change. 


\section{Appendix A: Glossary}

- Moisture recycling: the process by which evapotranspiration in a specific location on the continent contributes to precipitation in another location on the continent.

- Re-evaporation cycle: evapotranspiration of precipitating moisture in the same location.

- Cascading moisture recycling (CMR): moisture recycling that involves at least one re-evaporation cycle on the way.

- Direct moisture recycling (DMR): moisture recycling with no intervening re-evaporation cycle on the way.

- Intermediary: location where moisture runs through the re-evaporation cycle on its way between two locations on the continent (only in the case of CMR).

- Pathway of moisture recycling: set of locations on land involved in moisture recycling. A DMR pathway includes only the starting (evapotranspiration) and the destination (precipitation) locations, while a CMR pathway includes the starting, the destination and the intermediary locations.

- Optimal pathway: the pathway of moisture recycling that contributes most to moisture transport between two locations. It can be a direct or a cascading pathway.

- Direct source: land surface that contributes directly (i.e., through DMR) to rainfall over a given region.

- Cascading source: land surface that contributes indirectly (i.e., through CMR) to rainfall over a given region.

- Source: land surface that contributes directly or indirectly to rainfall over a given region.

- Direct sink: land surface that is dependent on evapotranspiration coming directly (i.e., through DMR) from a given region for local precipitation.

- Cascading sink: land surface that is dependent on evapotranspiration coming indirectly (i.e., through CMR) from a given region for local precipitation.

- Sink: land surface that is dependent on evapotranspiration coming directly or indirectly from a given region for local precipitation.

\section{Appendix B: Supplementary description of the method}

All grid cell measures are area-weighted as described in Zemp et al. (2014).

\section{B1 Cascading moisture recycling ratios}

To calculate the CMR ratios as defined in Sect. 2.3.2, we calculate the individual contributions of CMR pathways consisting of $k$ re-evaporation cycles $(k \in\{1, \ldots, n\})$, which add up to the total CMR contribution. We chose a maximum number of cycles $n=100$, while the contribution of pathways with a number of cycles larger than three is close to zero.

The fraction of precipitation in grid cell $j$ that comes from $\Omega$ through CMR involving only one re-evaporation cycle is

$\rho_{\Omega, j}^{(1)}=\frac{\sum_{i \notin \Omega} m_{i j} \cdot \rho_{\Omega, i}}{P_{j}}$,

where $\rho_{\Omega, i}$ is the direct precipitation recycling ratio for grid cell $i$ (Sect. 2.3.1). Following the same principle as in Eq. (B1), the fraction of precipitation in $j$ that comes from $\Omega$ through CMR involving $n$ re-evaporation cycles is

$\rho_{\Omega, j}^{(n)}=\frac{\sum_{i \notin \Omega} m_{i j} \cdot \rho_{\Omega, i}^{(n-1)}}{P_{j}}$,

where $\rho_{\Omega, i}^{(n-1)}$ is the fraction of precipitation in $i$ that comes from $\Omega$ through CMR involving $n-1$ re-evaporation cycles. $\rho_{\Omega}^{\text {casc }}$ is the sum of all individual contributions of the CMR pathways:

$\rho_{\Omega, j}^{\text {casc }}=\rho_{\Omega, j}^{(1)}+\ldots+\rho_{\Omega, j}^{(n)}$.

The fraction of evapotranspiration in grid cell $i$ that falls as precipitation over $\Omega$ after only one re-evaporation cycle is

$\varepsilon_{\Omega, i}^{(1)}=\frac{\sum_{j \notin \Omega} m_{i j} \cdot \varepsilon \Omega, j}{E_{i}}$,

where $\varepsilon_{\Omega, j}$ is the direct evapotranspiration recycling ratio for grid cell $j$ (Sect. 2.3.1). Similarly, the fraction of evapotranspiration in $i$ that falls as precipitation over $\Omega$ after $n$ re-evaporation cycles is

$\varepsilon_{\Omega, i}^{(n)}=\frac{\sum_{j \notin \Omega} m_{i j} \cdot \varepsilon_{\Omega, j}^{(n-1)}}{E_{i}}$,

where $\varepsilon_{\Omega, j}^{(n-1)}$ is the fraction of evapotranspiration in $j$ that precipitates over $\Omega$ after $n-1$ re-evaporation cycles. $\varepsilon_{\Omega}^{\text {casc }}$ is the sum of the individual contribution of CMR pathways:

$\varepsilon_{\Omega, i}^{\text {casc }}=\varepsilon_{\Omega, i}^{(1)}+\ldots+\varepsilon_{\Omega, i}^{(n)}$. 


\section{B2 Robustness of the cascading moisture recycling ratios}

In order to test the robustness of the cascading precipitation recycling ratios, we have computed the steps explained in B1 with $\Omega$ being the ocean. Thus, $\rho_{\mathrm{o}}$ is the fraction of precipitation that comes from the ocean without any re-evaporation cycle on the way and $\rho_{\mathrm{o}}^{(k)}$ is the fraction of precipitation that comes from the ocean with $k$ re-evaporation cycle(s) on the way $(k=1, \ldots n)$. We confirm that

- The sum $\rho_{\mathrm{o}}+\rho_{o}^{(1)}+\rho_{o}^{(2)}+\ldots+\rho_{\mathrm{o}}^{(n)}$ is equal to 1 . This is easy to interpret as all the precipitation in a location must have always come from the ocean (either directly or after a certain number of re-evaporation cycles).

- The sum $\rho_{o}^{(1)}+\rho_{o}^{(2)}+\ldots+\rho_{o}^{(n)}$ represents the fraction of precipitation that comes from the ocean with at least one re-evaporation cycle. It is equal to the continental recycling ratio $\rho_{c}$ (see Sect. 2.3.1 and van der Ent et al., 2010).

- The sum $\rho_{o}^{(2)}+\ldots+\rho_{\mathrm{o}}^{(n)}$ is the fraction of precipitation that comes from the ocean with at least two reevaporation cycles. It is equal to $\Delta P_{\mathrm{c}} / P$, introduced as the fraction of precipitation that has been evaporated at least twice on the continent (see Sect. 2.4).

We obtained thus the same results using different metrics. We cannot test the evaporation recycling ratio the same way because $\Delta E_{\mathrm{c}} / E$ quantifies the fraction of evapotranspiration that is involved in cascading moisture recycling (i.e., that comes from the continent and precipitates further over the continent), while $\epsilon_{o}^{(2)}+\ldots+\epsilon_{\mathrm{o}}^{(n)}$ would be the fraction of evapotranspiration that runs through at least two reevaporation cycles before precipitating over the ocean. This is also the reason why the two methodologies are needed even if they lead to the same results for the previously mentioned case.

\section{B3 Quantifying cascading moisture recycling}

To quantify the contribution of CMR in $\Omega$ to total moisture in- and outflow, we modify the network such that the oceanic moisture (i.e., that has been last evaporated over the ocean) is only re-evaporated once in $\Omega$. By doing so, we remove CMR in $\Omega$. We then derive the corresponding reduction in total moisture inflow from $\Omega$ or outflow towards $\Omega$ :

$\Delta P_{j \leftarrow \Omega}=P_{j \leftarrow \Omega}-P_{j \leftarrow \Omega, o}$,
$\Delta E_{i \rightarrow \Omega}=E_{i \rightarrow \Omega}-E_{i \rightarrow \Omega, o}$,

where $P_{j \leftarrow \Omega}=\sum_{i \in \Omega} m_{i j}$ is the precipitation in $j$ originating from $\Omega, E_{i \rightarrow \Omega}=\sum_{j \in \Omega} m_{i j}$ is the evapotranspiration in $i$ that precipitates over $\Omega, P_{j \leftarrow \Omega, o}=\sum_{i \in \Omega} m_{i j \leftarrow \text { ocean }}$ is the precipitation in $j$ originating from the re-evaporation of oceanic moisture in $\Omega$ and $E_{i \rightarrow \Omega, o}=\sum_{j \in \Omega} m_{i j \leftarrow \text { ocean }}$ is the evapotranspiration of oceanic moisture in $i$ that precipitates over $\Omega$. Thus, $\Delta P_{j \leftarrow \Omega}$ is the precipitation in $j$ originating from the re-evaporation of continental moisture in $\Omega$ and $\Delta E_{i \rightarrow \Omega}$ is the re-evaporation of continental moisture in $i$ that precipitates over $\Omega$. If $\Omega$ is the entire South American continent (the intermediary region), $\Delta P_{j \leftarrow \Omega}$ becomes $\Delta \boldsymbol{P}_{\mathbf{c}}\left(\Delta \boldsymbol{P}_{\mathrm{m}}\right)$ and $\Delta \boldsymbol{E}_{i \rightarrow \Omega}$ becomes $\Delta \boldsymbol{E}_{\mathrm{c}}\left(\Delta \boldsymbol{E}_{\mathrm{m}}\right)$ as defined in Sect. 2.4.

To remove CMR in $\Omega$, we derive for each grid cell the evapotranspiration of moisture from oceanic origin as in Eq. (1):

$E_{i \leftarrow \text { ocean }}=\frac{E_{i}}{P_{i}} \cdot P_{i \leftarrow \text { ocean }}$,

where $P_{i \leftarrow \text { ocean }}$ is the precipitation from oceanic origin in $i\left(P_{j \leftarrow \text { ocean }}=P_{j}-P_{j \leftarrow \text { continent }}\right.$ and $P_{j \leftarrow \text { continent }}=$ $\sum_{i \in \text { continent }} m_{i j}$; see Fig. B1). Using the same assumption, we get the moisture transport between each pair of grid cells $i$ and $j$ that results from evapotranspiration of moisture from oceanic origin only:

$m_{i j \leftarrow \text { ocean }}=\frac{m_{i j}}{E_{i}} \cdot E_{i \leftarrow \text { ocean }}$.

At this stage, $m_{i j \leftarrow \text { ocean }}$ can be interpreted as the evapotranspiration in $i$ that precipitates in $j$ and that has been evaporated from the ocean before that $\left(m_{i j \leftarrow \text { ocean }}<m_{i j}\right)$.

\section{B4 Complex network analysis}

\section{B4.1 Clustering coefficient associated with Middleman motifs}

Mathematically, the clustering coefficient $C$ of the grid cell $i$ is

$C_{i}=\frac{t_{i}}{T_{i}}$,

where $t_{i}$ is the number of Middleman motifs that $i$ forms and $T_{i}$ is the total number of that motif that $i$ could have formed according to its number of incoming and outgoing arrows. To give more weight to a motif involved in the transport of a larger amount of moisture, we assign a weight to each motif. In agreement with Fagiolo (2007), the weight of a motif is defined as the geometric mean of the weights of the three involved arrows. The weighted counterpart of Eq. (B10) is

$\widetilde{C}_{i}=\frac{\widetilde{t_{i}}}{T_{i}}$,

with $\widetilde{t}_{i}$ the weighted counterpart of $t_{i}$ (i.e., the sum of the weights of the Middleman motifs that is formed by $i$ ).

The calculation of the clustering coefficient is derived from the methodology of a previous study (Fagiolo, 2007, Table 1) and has been corrected in order to account for the irregular sizes of the portion of the Earth's surface covered by the grid cells as explained in Zemp et al. (2014). 


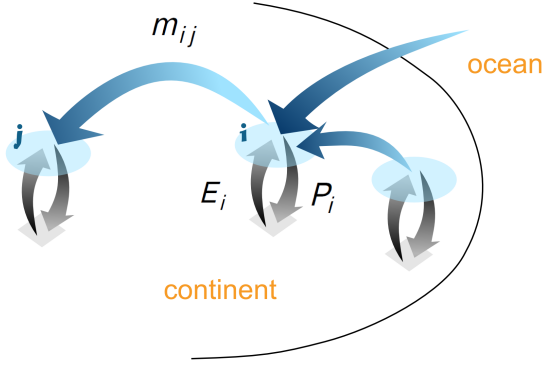

(a)

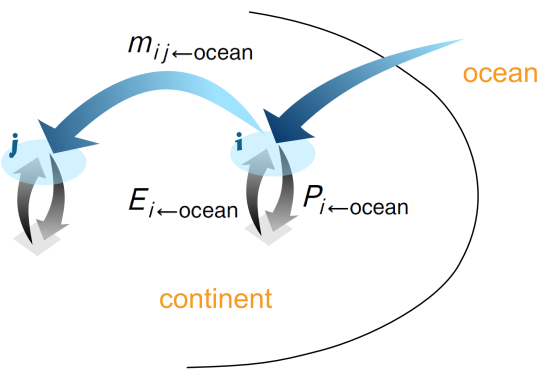

(b)

Figure B1. Scheme explaining the removal of CMR. Originally, the precipitation in the grid cell $i\left(P_{i}\right)$ is composed of oceanic and continental moisture. The total incoming moisture is evaporated in $i\left(E_{i}\right)$ and some part of it contributes to precipitation in the grid cell $j\left(m_{i j}\right)(\mathbf{a})$. If we forbid the re-evaporation of continental precipitation, only the precipitation in $i$ that has oceanic origin $\left(P_{i \leftarrow \text { ocean }}\right)$ is evaporated in $i$ $\left(E_{i \leftarrow \text { ocean }}\right)$ and can contribute to precipitation in $j\left(m_{i j \leftarrow \text { ocean }}\right)$. By doing so, we remove cascading recycling of continental moisture from the network.

We define the matrix $\mathbf{P}=\left\{p_{i j}^{1 / 3}\right\}$ obtained by taking the cubic root of each entry $p_{i j}$, with $p_{i j}$ being the weight of the arrow originating from $i$ and pointing towards $j$. Here, in order to avoid a strong correlation between the clustering coefficient and the mean evapotranspiration and precipitation, we chose this weight to be $p_{i j}=m_{i j}^{2} /\left(E_{i} P_{j}\right)$. According to Fagiolo (2007), the numerator of Eq. (B11) is derived as the $i$ th element of the main diagonal of a product of matrices $\widetilde{t_{i}}=\left(\mathbf{P} \mathbf{P}^{\mathrm{T}} \mathbf{P}\right)_{i i}$, where $\mathbf{P}^{\mathrm{T}}$ is the transpose of $\mathbf{P}$.

The denominator of Eq. (B11) is $T_{i}=k_{i}^{\text {in }} k_{i}^{\text {out }}$, where $k_{i}^{\text {in }}$ is the number of arrows pointing towards $i$ and $k_{i}^{\text {out }}$ the number of arrows originating from $i$ :

$k_{i}^{\text {in }}=\sum_{j \neq i} a_{j i}$,

$k_{i}^{\text {out }}=\sum_{j \neq i} a_{i j}$,

where $a_{i j}=1$ if there is an arrow originating from $i$ and pointing towards $j$; otherwise, $a_{i j}=0$. In order to compare the results for the two seasons, we normalize $\widetilde{C}$ with the maximum observed value for each network.

\section{B4.2 Optimal pathway}

In complex network theory, many centrality measures (e.g., closeness and betweenness) are based on the concept of the shortest path. The shortest path is usually defined as the pathway between nodes that has the minimum cost. In this work, it is defined as the pathway that contributes most to the moisture transport between two grid cells. As this pathway is not necessarily the shortest one in terms of geographical distance, we will call it optimal pathway to avoid confusion.

Let $\left(r_{1}, r_{2}, \ldots, r_{n}\right)$ be the intermediary grid cells in a CMR pathway from grid cell $i$ to grid cell $j$. The contribution of this pathway is defined as the fraction of precipitation in $j$

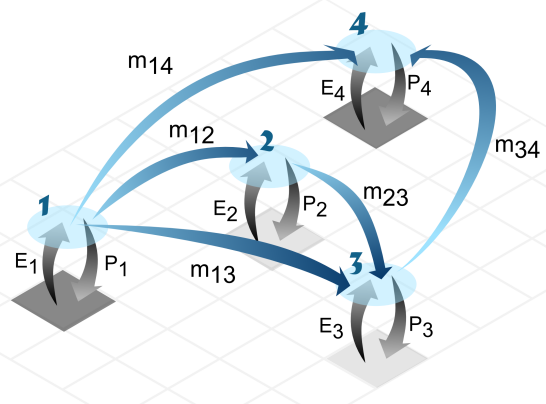

Figure B2. Different CMR pathways from grid cell 1 to grid cell 4. The contribution of the direct pathway is $W_{1,4}=m_{14} / \mathrm{P}_{4}$, the contribution of the path involving one re-evaporation cycle in grid cell 3 is $W_{1,3,4}=m_{13} / \mathrm{P}_{3} \cdot m_{14} / \mathrm{P}_{4}$ and the contribution of the path involving re-evaporation cycles in grid cells 2 and 3 is $W_{1,2,3,4}=$ $m_{12} / \mathrm{P}_{2} \cdot m_{13} / \mathrm{P}_{3} \cdot m_{14} / \mathrm{P}_{4}$. The legend is the same as that in Fig. 3 .

that comes from evapotranspiration in $i$ through CMR:

$W_{i, r_{1}, \ldots, r_{n}, j}=\frac{m_{i r_{1}}}{P_{r_{1}}} \cdot \prod_{l=1}^{n-1} \frac{m_{r_{l} r_{l+1}}}{P_{r_{l+1}}} \cdot \frac{m_{r_{n} j}}{P_{j}}$.

An example of pathway contributions is provided in Fig. B2. The contribution of each existing pathway is calculated between any pair of grid cells in the network. The optimal pathway is the path with the maximum contribution.

To find the optimal pathway, we use the method shortest_paths in the package iGraph for Python based on an algorithm proposed by Dijkstra (1959). In this method, the cost of a pathway is calculated as the sum of the weight of its arrows. In order to adapt the method to our purpose, we chose the weight of the arrows as $w_{r_{l} r_{l+1}}=-\log \left(\frac{m_{r_{l} r_{l+1}}}{P_{r_{l+1}}}\right)$. The cost of a pathway from grid cell $i$ to grid cell $j$ as calcu- 

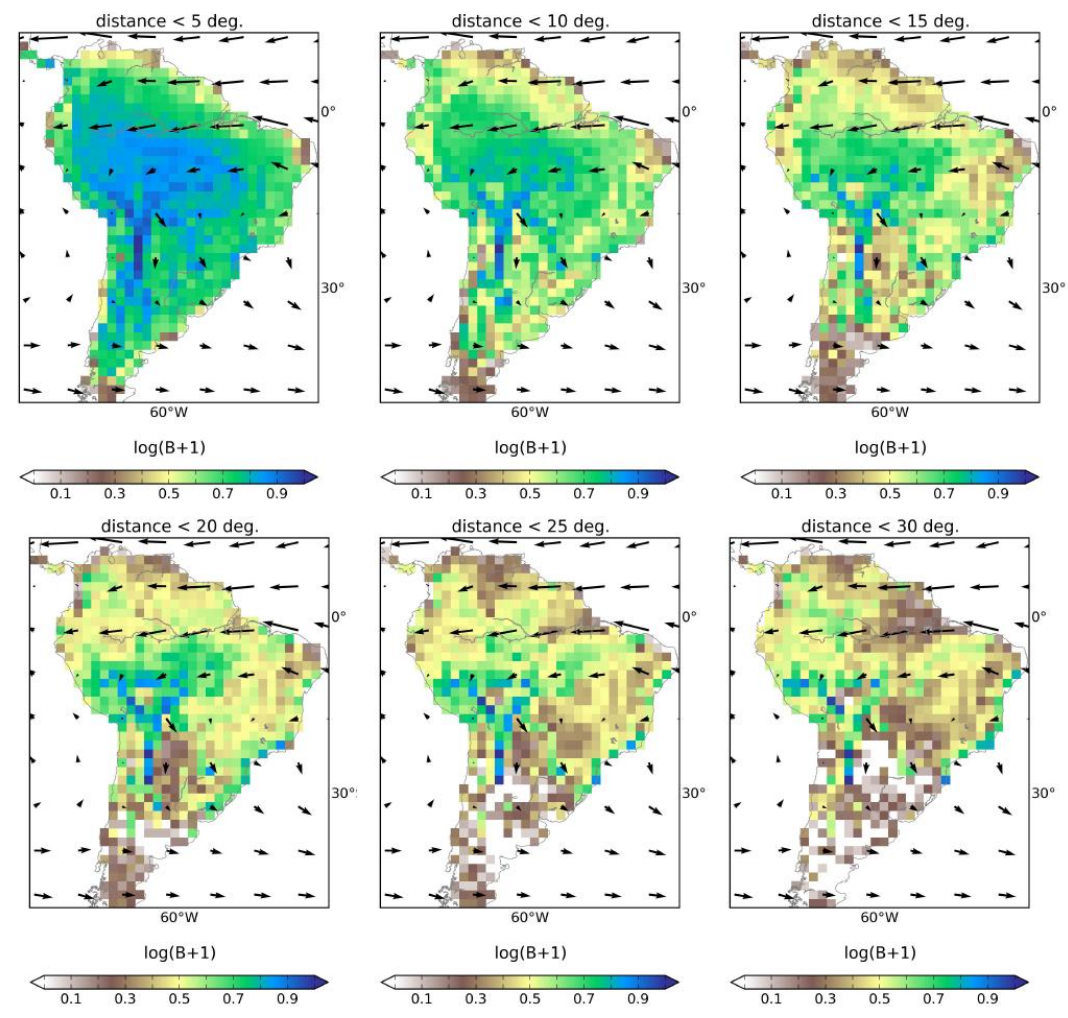

Figure B3. Betweenness centrality $(\boldsymbol{B})$ obtained for different thresholds (yearly average for the input MOD).

lated in iGraph becomes

$$
\begin{aligned}
W_{i, r_{1}, \ldots, r_{n}, j}^{\prime} & =w_{i r_{1}}+\sum_{l=1}^{n-1} w_{r_{l} r_{l+1}}+w_{r_{n} j} \\
& =-\log \left(\frac{m_{i r_{1}}}{P_{r_{1}}}\right)-\sum_{l=1}^{n-1} \log \left(\frac{m_{r_{l} r_{l+1}}}{P_{r_{l+1}}}\right) \\
& -\log \left(\frac{m_{r_{n} j}}{P_{j}}\right) \\
& =\log \left(\frac{1}{\frac{m_{i_{1}}}{P_{r_{1}}} \cdot \prod_{l=1}^{n-1}\left(\frac{m_{r_{l} r_{l+1}}}{P_{r_{l+1}}}\right) \cdot \frac{m_{r_{n} j}}{P_{j}}}\right) \\
& =\log \left(\frac{1}{W_{i, r_{1}, \ldots, r_{n}, j}}\right) .
\end{aligned}
$$

Because the optimal pathway is defined as the pathway with the minimum cost $W^{\prime}$, it corresponds to the pathway with the maximum contribution $W$ as defined above.

\section{B4.3 Betweenness centrality}

Mathematically, betweenness of the grid cell $i$ is the number of optimal pathways between any pair of grid cells that pass through $i$ :

$B_{i}=\sum_{j k} \frac{\sigma_{j k}(i)}{\sigma_{j k}}$

where $\sigma_{j k}$ is the total number of optimal pathways that connect $j$ and $k$ in the network and $\sigma_{j k}(i)$ is the number of these optimal pathways that pass through the grid cell $i . B$ reaches values between 0 and $(2)=\left(N^{2}-3 N+2\right) / 2$ with $N$ the number of grid cells. To calculate it, we used the method betweenness in the package iGraph for Python following the algorithm proposed by (Newman, 2001). This measure is then shifted to a logarithm scale $(\log 10(B+1))$ and normalized by the maximum obtained value. Figure B3 shows the $B$ for different thresholds in the geographical distance of the links excluded from the network. 
Acknowledgements. This paper was developed within the scope of the IRTG 1740/TRP 2011/50151-0, funded by the DFG/FAPESP. J. Donges acknowledges funding from the Stordalen Foundation and BMBF (project GLUES), R. J. van der Ent from NWO/ALW and A. Rammig from the EU-FP7 AMAZALERT (raising the alert about critical feedbacks between climate and long-term land use change in the Amazon) project, grant agreement no. 282664. We thank K. Thonicke and P. Keys for comments on the manuscript, P. Manceaux for his help on designing the network schemes and B. Mueller for her contribution on the data pre-processing.

Edited by: J.-Y. C. Chiu

\section{References}

Adler, R. F., Huffman, G. J., Chang, A., Ferraro, R., Xie, P. P., Janowiak, J., Rudolf, B., Schneider, U., Curtis, S., Bolvin, D., Gruber, A., Susskind, J., Arkin, P., and Nelkin, E.: The version2 global precipitation climatology project (GPCP) monthly precipitation analysis (1979-present), J. Hydrometeorol., 4, 11471167, 2003.

Arraut, J. M. and Satyamurty, P.: Precipitation and water vapor transport in the Southern Hemisphere with emphasis on the South American region, J. Appl. Meteorol. Clim., 48, 19021912, 2009.

Arraut, J. M., Nobre, C., Barbosa, H. M., Obregon, G., and Marengo, J.: Aerial rivers and lakes: looking at large-scale moisture transport and its relation to Amazonia and to subtropical rainfall in South America, J. Climate, 25, 543-556, 2012.

Bagley, J. E., Desai, A. R., Harding, K. J., Snyder, P. K., and Foley, J. A.: Drought and deforestation: has land cover change influenced recent precipitation extremes in the Amazon?, J. Climate, 27, 345-361, 2014.

Betts, R., Cox, P., Collins, M., Harris, P., Huntingford, C., and Jones, C.: The role of ecosystem-atmosphere interactions in simulated Amazonian precipitation decrease and forest dieback under global climate warming, Theor. Appl. Climatol., 78, 157$175,2004$.

Boers, N., Bookhagen, B., Marwan, N., Kurths, J., and Marengo, J.: Complex networks identify spatial patterns of extreme rainfall events of the South American Monsoon System, Geophys. Res. Lett., 40, 4386-4392, 2013.

Bosilovich, M. G. and Chern, J.-D.: Simulation of water sources and precipitation recycling for the MacKenzie, Mississippi, and Amazon River basins, J. Hydrometeorol., 7, 312-329, 2006.

Brubaker, K. L., Entekhabi, D., and Eagleson, P. S.: Estimation of continental precipitation recycling, J. Climate, 6, 1077-1089, 1993.

Burde, G. I. and Zangvil, A.: The estimation of regional precipitation recycling. Part I: Review of recycling models, J. Climate, 14, 2497-2508, 2001.

Burde, G. I., Gandush, C., and Bayarjargal, Y.: Bulk recycling models with incomplete vertical mixing. Part II: Precipitation recycling in the Amazon basin, J. Climate, 19, 1473-1489, 2006.

Chen, M. Y., Shi, W., Xie, P. P., Silva, V. B. S., Kousky, V. E., Higgins, R. W., and Janowiak, J. E.: Assessing objective techniques for gauge-based analyses of global daily precipitation, J. Geo- phys. Res.-Atmos., 113, D04110, doi:10.1029/2007JD009132, 2008.

Cox, P. M., Betts, R. A., Collins, M., Harris, P. P., Huntingford, C., and Jones, C. D.: Amazonian forest dieback under climatecarbon cycle projections for the 21st century, Theor. Appl. Climatol., 78, 137-156, 2004.

Da Silva, R. R., Werth, D., and Avissar, R.: Regional impacts of future land-cover changes on the Amazon basin wet-season climate, J. Climate, 21, 1153-1170, 2008.

Dee, D. and Uppala, S.: Variational bias correction in ERA-Interim, no. 575 in Technical Memorandum, ECMWF, Shinfield Park, Reading, England, 2008.

Dee, D. P., Uppala, S. M., Simmons, A. J., Berrisford, P., Poli, P., Kobayashi, S., Andrae, U., Balmaseda, M. A., Balsamo, G., Bauer, P., Bechtold, P., Beljaars, A. C. M., van de Berg, L., Bidlot, J., Bormann, N., Delsol, C., Dragani, R., Fuentes, M., Geer, A. J., Haimberger, L., Healy, S. B., Hersbach, H., Hólm, E. V., Isaksen, L., Kållberg, P., Köhler, M., Matricardi, M., McNally, A. P., Monge-Sanz, B. M., Morcrette, J.-J., Park, B.-K., Peubey, C., de Rosnay, P., Tavolato, C., Thépaut, J.-N., and Vitart, F.: The ERA-Interim reanalysis: configuration and performance of the data assimilation system, Q. J. Roy. Meteor. Soc., 137, 553-597, 2011.

Dijkstra, E. W.: A note on two problems in connexion with graphs, Num. Math., 1, 269-271, 1959.

Dirmeyer, P. A., Brubaker, K. L., and DelSole, T.: Import and export of atmospheric water vapor between nations, J. Hydrol., 365, 11 22, 2009.

Donges, J. F., Zou, Y., Marwan, N., and Kurths, J.: Complex networks in climate dynamics - Comparing linear and nonlinear network construction methods, Eur. Phys. J.-Spec. Top., 174, 157179, 2009a.

Donges, J. F., Zou, Y., Marwan, N., and Kurths, J.: The backbone of the climate network, Europhys. Lett., 87, 48007 , doi:10.1209/0295-5075/87/48007, 2009b.

Drumond, A., Nieto, R., Gimeno, L., and Ambrizzi, T.: A Lagrangian identification of major sources of moisture over Central Brazil and La Plata basin, J. Geophys. Res., 113, D14128, doi:10.1029/2007JD009547, 2008.

Drumond, A., Marengo, J., Ambrizzi, T., Nieto, R., Moreira, L., and Gimeno, L.: The role of the Amazon Basin moisture in the atmospheric branch of the hydrological cycle: a Lagrangian analysis, Hydrol. Earth Syst. Sci., 18, 2577-2598, doi:10.5194/hess-182577-2014, 2014.

Eltahir, E. A. B. and Bras, R. L.: Precipitation recycling in the Amazon basin, Q. J. Roy. Meteor. Soc., 120, 861-880, 1994.

Fagiolo, G.: Clustering in complex directed networks, Phys. Rev. E, 76, 026107, doi:10.1103/PhysRevE.76.026107, 2007.

Figueroa, S. N. and Nobre, C. A.: Precipitation distribution over central and western tropical South America, Climanalise, 5, 3645, 1990.

Franchito, S. H., Rao, V. B., Vasques, A. C., Santo, C. M. E., and Conforte, J. C.: Validation of TRMM precipitation radar monthly rainfall estimates over Brazil, J. Geophys. Res.-Atmos., 114, D02105, doi:10.1029/2007JD009580, 2009.

Freeman, L. C.: A set of measures of centrality based on betweenness, Sociometry, 40, 35-41, 1977. 
Gat, J. and Matsui, E.: Atmospheric water balance in the Amazon basin: an isotopic evapotranspiration model, J. Geophys. Res.Atmos., 96, 13179-13188, 1991.

Goessling, H. F. and Reick, C. H.: Continental moisture recycling as a Poisson process, Hydrol. Earth Syst. Sci., 17, 4133-4142, doi:10.5194/hess-17-4133-2013, 2013.

Grimm, A. M., Vera, C. S., and Mechoso, C. R.: The South American Monsoon System, in: The Third International Workshop on Monsoons, World Meteorological Organizations, Hangzhou, 111-129, 2-6 November 2004.

Hasler, N., Werth, D., and Avissar, R.: Effects of tropical deforestation on global hydroclimate: a multimodel ensemble analysis, J. Climate, 22, 1124-1141, 2009.

Hirota, M., Holmgren, M., Van Nes, E. H., and Scheffer, M.: Global resilience of tropical forest and savanna to critical transitions, Science, 334, 232-235, 2011.

Huffman, G. J., Adler, R. F., Rudolf, B., Schneider, U., and Keehn, P. R.: Global precipitation estimates based on a technique for combining satellite-based estimates, rain-gauge analysis and NWP model precipitation information, J. Climate, 8, 1284-1295, 1995.

Huffman, G. J., Adler, R. F., Bolvin, D. T., Gu, G., Nelkin, E. J., Bowman, K. P., Hong, Y., Stocker, E. F., and Wolff, D. B.: The TRMM Multisatellite Precipitation Analysis (TMPA): quasi-global, multiyear, combined-sensor precipitation estimates at fine scales, J. Hydrometeorol., 8, 38-55, 2007.

Keys, P. W., van der Ent, R. J., Gordon, L. J., Hoff, H., Nikoli, R., and Savenije, H. H. G.: Analyzing precipitationsheds to understand the vulnerability of rainfall dependent regions, Biogeosciences, 9, 733-746, doi:10.5194/bg-9-733-2012, 2012.

Keys, P. W., Barnes, E. A., van der Ent, R. J., and Gordon, L. J.: Variability of moisture recycling using a precipitationshed framework, Hydrol. Earth Syst. Sci., 18, 3937-3950, doi:10.5194/hess-18-3937-2014, 2014.

Kim, J.-E. and Alexander, M. J.: Tropical precipitation variability and convectively coupled equatorial waves on submonthly time scales in reanalyses and TRMM, J. Climate, 26, 3013-3030, 2013.

Knox, R., Bisht, G., Wang, J., and Bras, R.: Precipitation variability over the forest-to-nonforest transition in southwestern Amazonia, J. Climate, 24, 2368-2377, 2011.

Lean, J. and Warrilow, D. A.: Simulation of the regional climatic impact of Amazon deforestation, Nature, 342, 411-413, 1989.

Lewis, S. L., Brando, P. M., Phillips, O. L., van der Heijden, G. M., and Nepstad, D.: The 2010 amazon drought, Science, 331, 554$554,2011$.

Liebman, B., Kiladis, G. N., Marengo, J. A., Ambrizzi, T., and Glick, J. D.: Submonthly convective variability over South America and the South Atlantic convergence zone, J. Climate, 12, 1877-1891, 1999.

Loarie, S. R., Lobell, D. B., Asner, G. P., Mu, Q., and Field, C. B.: Direct impacts on local climate of sugar-cane expansion in Brazil, Nature Clim. Change, 1, 105-109, 2011.

Ludescher, J., Gozolchiani, A., Bogachev, M. I., Bunde, A., Havlin, S., and Schellnhuber, H. J.: Improved El Niño forecasting by cooperativity detection, P. Natl. Acad. Sci. USA, 110, 1174211745, 2013.
Malik, N., Bookhagen, B., Marwan, N., and Kurths, J.: Analysis of spatial and temporal extreme monsoonal rainfall over South Asia using complex networks, Clim. Dynam., 39, 971-987, 2012.

Marengo, J. A., Soares, W. R., Saulo, C., and Nicolini, M.: Climatology of the low-level jet east of the Andes as derived from the NCEP-NCAR reanalyses: Characteristics and temporal variability, J. Climate, 17, 2261-2280, 2004.

Marengo, J. A.: Characteristics and spatio-temporal variability of the Amazon River Basin Water Budget, Clim. Dynam., 24, 1122, 2005.

Marengo, J. A.: On the hydrological cycle of the Amazon basin: a historical review and current state-of-the-art, Rev. Brasil. Meteorol., 21, 1-19, 2006.

Marengo, J. A., Nobre, C. A., Tomasella, J., Oyama, M. D., Sampaio de Oliveira, G., De Oliveira, R., Camargo, H., Alves, L. M., and Brown, I. F.: The drought of Amazonia in 2005, J. Climate, 21, 495-516, 2008.

Martinez, J. A. and Dominguez, F.: Sources of Atmospheric Moisture for the La Plata River Basin, J. Climate, 27, 6737-6753, doi:10.1175/JCLI-D-14-00022.1, 2014.

Medvigy, D., Walko, R. L., and Avissar, R.: Effects of deforestation on spatiotemporal distributions of precipitation in South America, J. Climate, 24, 2147-2163, 2011.

Miguez-Macho, G. and Fan, Y.: The role of groundwater in the Amazon water cycle. 2. Influence on seasonal soil moisture and evapotranspiration, J. Geophys. Res., 117, D15114, doi:10.1029/2012JD017540, 2012.

Milo, R., Shen-Orr, S., Itzkovitz, S., Kashtan, N., Chklovskii, D., and Alon, U.: Network motifs: simple building blocks of complex networks, Science, 298, 824-827, 2002.

Monteith, J.: Evaporation and environment, Sym. Soc. Exp. Biol., 19, 205-234, 1965.

Morton, D. C., Nagol, J., Carabajal, C. C., Rosette, J., Palace, M., Cook, B. D., Vermote, E. F., Harding, D. J., and North, P. R. J.: Amazon forests maintain consistent canopy structure and greenness during the dry season, Nature, 506, 221-224, 2014.

Mu, Q., Zhao, M., and Running, S. W.: Improvements to a MODIS global terrestrial evapotranspiration algorithm, Remote Sens. Environ., 115, 1781-1800, 2011.

Mueller, B., Seneviratne, S. I., Jimenez, C., Corti, T., Hirschi, M., Balsamo, G., Ciais, P., Dirmeyer, P., Fisher, J. B., Guo, Z., Jung, M., Maignan, F., McCabe, M. F., Reichle, R., Reichstein, M., Rodell, M., Sheffield, J., Teuling, A. J., Wang, K., Wood, E. F. and Zhang, Y.: Evaluation of global observations-based evapotranspiration datasets and IPCC AR4 simulations, Geophys. Res. Lett., 38, L06402, doi:10.1029/2010GL046230, 2011.

Mueller, B., Hirschi, M., Jimenez, C., Ciais, P., Dirmeyer, P. A., Dolman, A. J., Fisher, J. B., Jung, M., Ludwig, F., Maignan, F., Miralles, D. G., McCabe, M. F., Reichstein, M., Sheffield, J., Wang, K., Wood, E. F., Zhang, Y., and Seneviratne, S. I.: Benchmark products for land evapotranspiration: LandFluxEVAL multi-data set synthesis, Hydrol. Earth Syst. Sci., 17, 3707-3720, doi:10.5194/hess-17-3707-2013, 2013.

Myers, N., Mittermeier, R. A., Mittermeier, C. G., Da Fonseca, G. A. B., and Kent, J.: Biodiversity hotspots for conservation priorities, Nature, 403, 853-858, 2000.

Nepstad, D. C., de Carvalho, C. R., Davidson, E. A., Jipp, P. H., Lefebvre, P. A., Negreiros, G. H., da Silva, E. D., Stone, T. A., Trumbore, S. E., and Vieira, S.: The role of deep roots in the hy- 
drological and carbon cycles of Amazonian forests and pastures, Nature, 372, 666-669, 1994.

New, M., Hulme, M., and Jones, P.: Representing twentieth-century space-time climate variability. Part II: Development of 1901-96 monthly grids of terrestrial surface climate, J. Climate, 13, 22172238, 2000.

Newman, M. E. J.: Scientific collaboration networks. II. Shortest paths, weighted networks, and centrality, Phys. Rev. E, 64, 016132, doi:10.1103/PhysRevE.64.016132, 2001.

Nobre, C. A., Sellers, P. J., and Shukla, J.: Amazonian deforestation and regional climate change, J. Climate, 4, 957-988, 1991.

Nobre, P., Malagutti, M., Urbano, D. F., de Almeida, R. A., and Giarolla, E.: Amazon deforestation and climate change in a coupled model simulation, J. Climate, 22, 5686-5697, 2009.

Numaguti, A.: Origin and recycling processes of precipitating water over the Eurasian continent: experiments using an atmospheric general circulation model, J. Geophys. Res.-Atmos., 104, 19571972, 1999.

Oyama, M. D. and Nobre, C. A.: A new climate-vegetation equilibrium state for tropical South America, Geophys. Res. Lett., 30, 2199, doi:10.1029/2003GL018600, 2003.

Rockström, J., Falkenmark, M., Karlberg, L., Hoff, H., Rost, S., and Gerten, D.: Future water availability for global food production: the potential of green water for increasing resilience to global change, Water Resour. Res., 45, W00A12, doi:10.1029/2007WR006767, 2009.

Rozante, J. R. and Cavalcanti, I. F. A.: Regional Eta model experiments: SALLJEX and MCS development, J. Geophys. Res.Atmos., 113, D17106, doi:10.1029/2007JD009566, 2008.

Rozante, J. R., Moreira, D. S., de Goncalves, L. G. G., and Vila, D. A.: Combining TRMM and surface observations of precipitation: technique and validation over South America, Weather Forecast., 25, 885-894, 2010.

Ruhoff, A.: Predicting evapotranspiration in tropical biomes using MODIS remote sensing data, Ph.D. thesis, Federal University of Rio Grande do Sul, Porto Alegre, 2011.

Salati, E., Dall'Olio, A., Matsui, E., and Gat, J. R.: Recycling of water in the Amazon basin: an isotopic study, Water Resour. Res., 15, 1250-1258, doi:10.1029/WR015i005p01250, 1979.

Sampaio, G., Nobre, C., Costa, M. H., Satyamurty, P., SoaresFilho, B. S., and Cardoso, M.: Regional climate change over eastern Amazonia caused by pasture and soybean cropland expansion, Geophys. Res. Lett., 34, L17709, doi:10.1029/2007GL030612, 2007.

Savenije, H. H. G.: The importance of interception and why we should delete the term evapotranspiration from our vocabulary, Hydrol. Process., 18, 1507-1511, 2004.

Shukla, J., Nobre, C., and Sellers, P.: Amazon deforestation and climate change, Science, 247, 1322-1325, 1990.
Spracklen, D. V., Arnold, S. R., and Taylor, C. M.: Observations of increased tropical rainfall preceded by air passage over forests, Nature, 489, 282-285, 2012.

Sudradjat, A., Brubaker, K., and Dirmeyer, P.: Precipitation source/sink connections between the Amazon and La Plata River basins, in: AGU Fall Meeting Abstracts, vol. 1, p. 0830, San Francisco, California, 6-10 December 2002.

Trenberth, K. E.: Atmospheric moisture recycling: role of advection and local evaporation, J. Climate, 12, 1368-1381, 1999.

Tsonis, A. A., Swanson, K. L., and Wang, G.: On the role of atmospheric teleconnections in climate, J. Climate, 21, 2990-3001, 2008.

van der Ent, R. J., Savenije, H. H. G., Schaefli, B., and Steele-Dunne, S. C.: Origin and fate of atmospheric moisture over continents, Water Resour. Res., 46, W09525, doi:10.1029/2010WR009127, 2010.

van der Ent, R. J. and Savenije, H. H. G.: Length and time scales of atmospheric moisture recycling, Atmos. Chem. Phys., 11, 1853 1863, doi:10.5194/acp-11-1853-2011, 2011.

van der Ent, R. J., Tuinenburg, O. A., Knoche, H.-R., Kunstmann, H., and Savenije, H. H. G.: Should we use a simple or complex model for moisture recycling and atmospheric moisture tracking?, Hydrol. Earth Syst. Sci., 17, 4869-4884, doi:10.5194/hess17-4869-2013, 2013.

van der Ent, R. J., Wang-Erlandsson, L., Keys, P. W., and Savenije, H. H. G.: Contrasting roles of interception and transpiration in the hydrological cycle - Part 2: Moisture recycling, Earth Syst. Dynam. Discuss., 5, 281-326, doi:10.5194/esdd-5-2812014, 2014.

Vera, C., Baez, J., Douglas, M., Emmanuel, C. B., Marengo, J., Meitin, J., Nicolini, M., Nogues-Paegle, J., Paegle, J., Penalba, O., Salio, P., Saulo, C., Silva Dias, M. A., Silva Dias, P., and Zipser, E.: The South American low-level jet experiment, B. Am. Meteorol. Soc., 87, 63-77, 2006.

Victoria, R. L., Martinelli, L. A., Mortatti, J., and Richey, J.: Mechanisms of water recycling in the Amazon basin: isotopic insights, Ambio, 20, 384-387, 1991.

Walker, R., Moore, N. J., Arima, E., Perz, S., Simmons, C., Caldas, M., Vergara, D., and Bohrer, C.: Protecting the Amazon with protected areas, P. Natl. Acad. Sci. USA, 106, 10582-10586, 2009.

Werth, D. and Avissar, R.: The local and global effects of Amazon deforestation, J. Geophys. Res.-Atmos., 107, 1322-1325, 2002.

Zemp, D. C., Wiedermann, M., Kurths, J., Rammig, A., and Donges, J. F.: Node-weighted measures for complex networks with directed and weighted edges for studying continental moisture recycling, Europhys. Lett., 107, 58005, doi:10.1209/02955075/107/58005, 2014. 